\title{
Blocking Stroke-Induced Immunodeficiency Increases CNS Antigen-Specific Autoreactivity But Does Not Worsen Functional Outcome after Experimental Stroke
}

\author{
Christine Römer, ${ }^{1,2}$ Odilo Engel, ${ }^{1,2}$ Katarzyna Winek, ${ }^{1,2}$ Sonja Hochmeister, ${ }^{7}$ Tian Zhang, ${ }^{1,2}$ Georg Royl, ${ }^{3,8}$ \\ Juliane Klehmet, ${ }^{3,5}$ Ulrich Dirnagl, ${ }^{1,2,3,5,6}$ Christian Meisel, ${ }^{4}$ and Andreas Meisel ${ }^{1,2,3,5}$ \\ ${ }^{1}$ Center for Stroke Research, ${ }^{2}$ Department for Experimental Neurology, ${ }^{3}$ Department of Neurology, ${ }^{4}$ Institute of Medical Immunology, and ${ }^{5}$ NeuroCure \\ Clinical Research Center, Charité Universitätsmedizin Berlin, 10098 Berlin, Germany, ${ }^{6} \mathrm{German}$ Center for Neurodegenerative Diseases, 10117 Berlin, \\ Germany, ${ }^{7}$ Department of Neurology, Medical University of Graz, 8010 Graz, Austria, and ${ }^{8}$ Department of Neurology, University of Lübeck, 23538 Lübeck, \\ Germany
}

Stroke-induced immunodepression (SIDS) is an essential cause of poststroke infections. Pharmacological inhibition of SIDS appears promising in preventing life-threatening infections in stroke patients. However, SIDS might represent an adaptive mechanism preventing autoreactive immune responses after stroke. To address this, we used myelin oligodendrocyte glycoprotein (MOG) T-cell receptor transgenic $(2 \mathrm{D} 2)$ mice where $>80 \%$ of peripheral $\mathrm{CD} 4{ }^{+} \mathrm{T}$ cells express a functional receptor for MOG. We investigated in a murine model of middle cerebral artery occlusion the effect of blocking SIDS by inhibiting body's main stress axes, the sympathetic nervous system (SNS) with propranolol and the hypothalamic-pituitary-adrenal axis (HPA) with mifepristone. Blockade of both stress axes robustly reduced infarct volumes, decreased infection rate, and increased long-term survival of $2 D 2$ and C57BL/6J wild-type mice. Despite these protective effects, blockade of SIDS increased CNS antigen-specific Type1 Thelper cell (Th1) responses in the brains of $2 D 2 \mathrm{mice} 14 \mathrm{~d}$ after middle cerebral artery occlusion. One month after experimental stroke, $2 D 2$ mice developed signs of polyradiculitis, which were diminished by SIDS blockade. Adoptive transfer of CD4 ${ }^{+}$T cells, isolated from $2 \mathrm{D} 2$ mice, into lymphocyte-deficient $\mathrm{Rag}$ - $1 \mathrm{KO}$ mice did not reveal differences between SIDS blockade and vehicle treatment in functional long-term outcome after stroke. In conclusion, inhibiting SIDS by pharmacological blockade of body's stress axes increases autoreactive CNS antigen-specific T-cell responses in the brain but does not worsen functional long-term outcome after experimental stroke, even in a mouse model where CNS antigen-specific autoreactive T-cell responses are boosted.

Key words: CNS autoreactivity; immunosuppression; mifepristone; murine stroke; propranolol; stroke-induced immunodeficiency syndrome

\section{Introduction}

Despite stroke being one of the major and increasing burdens to global health (Global Burden of Disease Study, 2012), therapeutic interventions in cerebral ischemia continue to be a challenge. Today, thrombolysis with tissue plasminogen activator is the only approved causal treatment but due to a narrow time window of $3 \mathrm{~h}$ ( $4.5 \mathrm{~h}$ in European countries), can only be applied in 1\%$8.5 \%$ of patients (Millan and Davalos, 2006). In the acute course

\footnotetext{
Received March 13, 2015; accepted April 3, 2015.

Author contributions: C.R., O.E., K.W., S.H., J.K., U.D., C.M., and A.M. designed research; C.R., O.E., K.W., S.H., and T.Z. performed research; G.R. and J.K. contributed unpublished reagents/analytic tools; C.R., K.W., T.Z., G.R., and A.M. analyzed data; C.R. and A.M. wrote the paper.

C.R. received NeuroCure Cluster of Excellence scholarship. The work was supported by the German Research Foundation (Exc 257; SFB TR43), the Federal Ministry of Education and Research (01 E0 08 01), and the European Community's Seventh Framework Programme (FP7/2007-2013; Grant Agreement 201024). We thank Dr. Rudolf Volkmer for providing MOG peptide; and Yvonne Amoneit, Sabine Kolodziej, and Marco Foddis for expert technical assistance.

The authors declare no competing financial interests.

Correspondence should be addressed to Dr. Andreas Meisel, Department for Experimental Neurology (CC15), Charité Universitätsmedizin Berlin, Charitéplatz 1, 10117 Berlin, Germany. E-mail: andreas.meisel@charite.de. DOI:10.1523/JNEUROSCI.1532-14.2015

Copyright $\odot 2015$ the authors $\quad 0270-6474 / 15 / 357777-18 \$ 15.00 / 0$
}

of the disease, stroke patients often develop complications (Kumar et al., 2010), such as pneumonia (Emsley and Hopkins, 2008), increasing morbidity and mortality (Katzan et al., 2003; Finlayson et al., 2011; Koennecke et al., 2011; Westendorp et al., 2011; Rocco et al., 2013). Susceptibility to infection after stroke is facilitated by systemic immunodepression, described as strokeinduced immunodeficiency syndrome (SIDS) (Prass et al., 2003; Meisel et al., 2005; Chamorro et al., 2012). This crosstalk between the CNS and immune system is mediated by sympathetic nervous system (SNS), hypothalamic-pituitary-adrenal axis (HPA), and vagus nerve (Tracey, 2002; Meisel et al., 2005; Chamorro et al., 2007).

Recently, immunomodulatory therapies targeting SIDS have been identified to prevent harmful poststroke infections (Meisel and Meisel, 2008). However, immunodepression after acute CNS injury may represent an adaptive response limiting tissue damage and preventing detrimental immune responses against CNS antigens (Meisel and Meisel, 2011). Thus, stimulating immune system after stroke might boost inflammation in the ischemic brain, worsening functional outcome.

CNS trauma has been associated with increased autoreactivity for $>80$ years (Rivers et al., 1933). Disruption of the blood-brain 
barrier and damage to brain parenchyma during stroke deliberates myelin and exposes brain antigens to peripheral immune cells (Wang et al., 1992; Kuchroo et al., 2002). The autonomic nervous system mitigates inflammation by reducing proinflammatory cytokine (IL-12, TNF- $\alpha$, IFN- $\gamma$ ) production, dampening innate and adaptive immune responses and immune memory (Livnat et al., 1985; Whalen and Bankhurst, 1990; Tuosto et al., 1994; Sanders et al., 1997; Woiciechowsky et al., 1999; Vega et al., 2003; Meisel et al., 2005). In particular, SNS and HPA regulate adaptive immunity and might therefore mitigate detrimental autoimmune responses mediated by Th1 and Th17 cells (Ando et al., 1989; Cua et al., 2003; Langrish et al., 2005).

Only a few pioneering experimental studies have addressed autoreactive immune responses and long-term consequences after stroke (Gee et al., 2008; Gee et al., 2009). One of the likely targets for CNS antigen-specific autoreactivity is myelin oligodendrocyte glycoprotein (MOG) in the outer layer of myelin (Brunner et al., 1989) capable of inducing pathogenic B- and T-cell responses with demyelination (Genain et al., 1996).

Here, we hypothesized that blocking SIDS enhances CNS antigen-specific autoreactivity and worsens functional outcome in a murine model of middle cerebral artery occlusion (MCAo). We used 2D2 mice in which the majority of peripheral CD4 ${ }^{+} \mathrm{T}$ cells express functional receptor for MOG (Bettelli et al., 2003) and prevented SIDS by blocking SNS and HPA mediated SIDS simultaneously with $\beta$-blocker propranolol and anti-glucocorticoid mifepristone (modified from Prass et al., 2003).

\section{Materials and Methods}

Animals and housing. Female C57BL/6J (Charles River Laboratories; RRID:IMSR_JAX:000664), 2D2 T-cell receptor (TCR) transgenic mice (strain name: C57BL/6-Tg(Tcra2D2,Tcrb2D2)1Kuch/J; stock number 006912; The Jackson Laboratory; RRID:IMSR_JAX:006912), and gender-mixed Rag-1KO mice (strain name: B6.129S7-Rag1 ${ }^{\text {tm1Mom/J; }}$ stock number 002216; The Jackson Laboratory; RRID:IMSR_JAX: 002096) were used in the study. Mice were 9-16 weeks old when entering the study. Animal division into groups was randomized, and experiments were performed in a blinded manner. Mice were housed in Charité animal facility with a $12 \mathrm{~h}$ light/dark cycle (lights on from 7:00 until 19:00). Cages were lined with chip bedding, enriched with a mouse tunnel and igloo (Plexx BV). Mice had ad libitum access to food (standard chow) and water (where study design indicates, water was replaced with an antibiotic solution). All animal experiments were conducted in accordance with the European Community Council Directives 86/609/EEC and German national laws and approved by local authority (Landesamt für Gesundheit und Soziales, Berlin, Germany).

Drug administration. Preventive antibiotic (enrofloxacin; Baytril $2.5 \%$ ) was administered to minimize interdependencies between infection and outcome parameters (Engel and Meisel, 2010; Hetze et al., 2013). Enrofloxacin was diluted in drinking water $(0.35 \mathrm{mg} / \mathrm{ml})$ and provided $24 \mathrm{~h}$ before MCAo surgery until $7 \mathrm{~d}$ after MCAo. Mice received additional $10 \mathrm{mg} / \mathrm{kg}$ of enrofloxacin intraperitoneally once a day for the first $3 \mathrm{~d}$ after MCAo. SNS and HPA (SNS/HPA) were blocked with propranolol and mifepristone, respectively (both from Sigma-Aldrich). Original injection scheme, drug preparation, and dosage for single treatments (Prass et al., 2003) were optimized for the current experiment. Mifepristone was dissolved in 100\% ethanol (Rotipuran, Carl Roth) at 30 $\mathrm{mg} / \mathrm{ml}$ on a heated water bath and diluted in sesame oil (Fluca Analytical, Sigma-Aldrich) until final concentration of $3 \mathrm{mg} / \mathrm{ml}$. Mifepristone was injected intraperitoneally ( $20 \mathrm{mg} / \mathrm{kg}$ ) 24 and $5 \mathrm{~h}$ before MCAo as well as at reperfusion (60 min after MCAo). Propranolol was dissolved in $0.9 \%$ $\mathrm{NaCl}$ (Fresenius Kabi Deutschland) at $3 \mathrm{mg} / \mathrm{ml}$ and administered intraperitoneally $(30 \mathrm{mg} / \mathrm{kg}$ ) at MCAo, 4 and $8 \mathrm{~h}$ after MCAo (see Fig. $1 A$ ). The vehicle group received diluents without active substance according to the same injection scheme.
Animal model of stroke. MCAo was performed according to the standard operating procedures of the laboratory (Dirnagl, 2012). In brief, anesthesia was induced with $2.5 \%$ isoflurane (Forene, Abbott) in $1 / 2$ mixture of $\mathrm{O}_{2} / \mathrm{N}_{2} \mathrm{O}$ and maintained at $1.0 \%-1.5 \%$ isoflurane. Siliconrubber-coated monofilament with a diameter of $0.19 \pm 0.01 \mathrm{~mm}$ (Doc$\mathrm{col}$ ) was introduced into the common carotid artery, advanced along the internal carotid artery to the origin of the MCA, and left there for $60 \mathrm{~min}$ until reperfusion. Body temperature was maintained with a heating pad. A drop of $2 \%$ lidocaine gel was applied to the wound for pain relief. Success of MCAo was verified applying the modified Bederson score (Bederson et al., 1986). After surgery, animals were allowed to recover in a heated cage before returning to home cages. Soft pellet food was provided postoperatively for $3 \mathrm{~d}$.

Cerebral blood flow (CBF) and diffusion-weighted imaging (DWI) measurement with MRI. As soon as the filament entered the origin of MCA, the head of the mouse was fixed using a stereotactic frame in magnet bore. Anesthesia was maintained at $0.8 \%-1.0 \%$ isoflurane in $1 / 2$ mixture of $\mathrm{O}_{2} / \mathrm{N}_{2} \mathrm{O}$. Body temperature was maintained at physiological range with a heated water jacket. During scan time, rectal temperature, electrocardiogram, and respiration rate were monitored with Small Animal Monitoring and Gating System (model 1025; SA Instruments; RRID: SciRes_000157). ${ }^{1} \mathrm{H}(300 \mathrm{MHz})$ mouse head surface radiofrequency coil was used as a receiver and a $72 \mathrm{~mm}$ linear volume resonator for transmission. Flow-sensitive alternating inversion recovery (FAIR)-MRI and DWI were performed on a 7T Bruker PharmaScan 70/16 magnet using Bruker Paravision 4.0 software (both from Bruker, software RRID:SciRes_000158) as described in detail elsewhere (Leithner et al., 2008). Briefly, pilot images were collected using a Fast Low Angle Shot sequence (TE $5 \mathrm{~ms}$, TR $307.7 \mathrm{~ms}$, FOV $25 \mathrm{~mm}$, a total of 27 slices with a thickness of $600 \mu \mathrm{m}$ in three views, $128 \times 128$ in plane resolution) to select an area between the olfactory bulb and the cerebellum. FAIR-MRI images were collected with a spin echo planar imaging (TE $42.55 \mathrm{~ms}$, TR $9122.7 \mathrm{~ms}$, FOV $20 \mathrm{~mm}$, imaging slice thickness $2 \mathrm{~mm}, 64 \times 64$ in plane resolution, inversion slab thickness $6 \mathrm{~mm}$, inversion recovery time $15.55 \mathrm{~ms}$, increment of inversion recovery time $800 \mathrm{~ms}$ ). Together, three slices $2 \mathrm{~mm}$ apart were selected; and for each slice, two series of 11 images (alternating slice selective inversion and slice nonselective inversion) were collected and hemispherical CBF calculated (Leithner et al., 2010). FAIR-MRI was followed by DWI using spin echo-echo planar imaging sequence (TE $40.93 \mathrm{~ms}$, TR $3000 \mathrm{~ms}$, FOV $20 \mathrm{~mm}$, imaging slice thickness and interslice distance $1 \mathrm{~mm}, 128 \times 128$ in plane resolution, total of 10 slices and 6 averages). FAIR-MRI and DWI were repeated $3 \mathrm{~h}$ after MCAo.

Hemispheric CBF was calculated from FAIR-MRI data as described previously (Leithner et al., 2008; Royl et al., 2009) using custom script routines based on MATLAB (The MathWorks; RRID:nlx_153890). From DWI imaging, the apparent diffusion coefficient (ADC) maps were calculated. Lesions visible in the ADC images were delineated with ImageJ (National Institutes of Health; RRID:nif-0000-30467) and lesion volumes calculated by multiplying with voxel size.

T2-weighted imaging for infarct volume determination. For quantification of ischemic lesion, animals were subjected to MRI $24 \mathrm{~h}, 48 \mathrm{~h}$, or $7 \mathrm{~d}$ after the MCAo surgery. Anesthesia was applied and physiological characteristics monitored as described above. T2-weighted images were acquired with a 7T Bruker PharmaScan 70/16 magnet, $20 \mathrm{~mm}$ quadratum volume resonator radiofrequency coil, and Bruker Paravision 4.0 software (Bruker) using Rapid Acquisition with Relaxation Enhancement (RARE) sequence (TE $36 \mathrm{~ms}$, TR $4200 \mathrm{~ms}$, FOV $28 \mathrm{~mm}$, 20 slices with a thickness of $500 \mu \mathrm{m}$ and interslice distance $500 \mu \mathrm{m}, 256 \times 256$ in plane resolution). Axial slices covered the distance between the olfactory bulb and the cerebellum. Acquired images were analyzed semiautomatically with Mayo Clinic Analyze software version 5.0 (Biomedical Imaging Resource, Analyze Direct, Analyze Software System; RRID:nif-000000263). The difference between hemispheric volumes (excluding the lesion) was divided with the volume of ipsilateral hemisphere and converted into percentage to obtain edema-corrected infarct volumes.

Bronchoalveolar lavage (BAL) and microbiology. Three days after MCAo, mice were anesthetized with an intraperitoneal injection of midazolam (5.0 mg/kg; Roche Pharma AG) and medetomidin $(0.5 \mathrm{mg} /$ $\mathrm{kg}$; Orion Pharma) and intubated with a $22 \mathrm{G}$ venous catheter (BD Bio- 
A

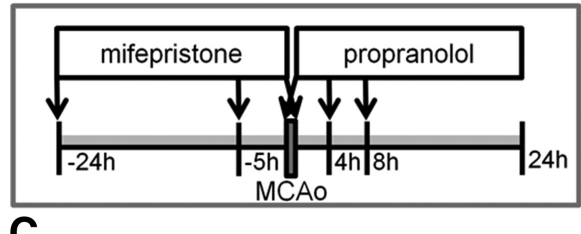

C

\section{Rag-1KO recipients:}



Figure 1. Study outline. Stroke-induced immunodeficiency was blocked by inhibition of SNS and HPA using $\beta$-blocker propranolol and glucocorticoid receptor antagonist mifepristone. $A$, Scheme illustrating time points of substance administration relative to MCAo surgery. The paradigm was applied in all experiments. $\boldsymbol{B}, \boldsymbol{C}$, Paradigm for adaptive cell transfer study. $\boldsymbol{B}$, Female $2 D 2$ donor mice received propranolol and mifepristone according to $A$ and underwent MRI for infarct volume measurement. On day 7, mice were sacrificed. Spleen and lymph nodes (cervical, mesenteric, inguinal, and lumbar) were used for separation of untouched CD4 ${ }^{+}$T cells through MACS. C, Two million of these cells were transferred intravenously to gender-mixed Rag- 1 KO recipients $6 \mathrm{~h}$ after MCA0. Rag-1KO mice were examined for functional outcome and neurological deficits using CatWalk gait analysis on days 10 and 30, modified EAE score day 7-30, and EMG on day 14 after MCA0. On day 30, animals were euthanized, and their brains and vertebrae containing nerve roots were analyzed for immune cell infiltration and axonal damage. 2D2 donor and Rag- 1 KO recipient mice received preventively enrofloxacin from $1 \mathrm{~d}$ before until $7 \mathrm{~d}$ after MCA0. CW, CatWalk gait analysis.

sciences PharMingen) under direct illumination with fiber optic (MacDonald et al., 2009). BAL was collected by flushing with $300 \mu \mathrm{l}$ of $0.9 \% \mathrm{NaCl}$. After the procedure, anesthesia was antagonized with a subcutaneous injection of flumazenil $(0.5 \mathrm{mg} / \mathrm{kg}$; Inresa Arzneimittel $)$ and atipamezolhydrochloride ( $2.5 \mathrm{mg} / \mathrm{kg}$; Orion Pharma). BAL fluid was serially diluted, plated on Lysogeny broth medium agar plates, and incubated at $37^{\circ} \mathrm{C}, 5 \% \mathrm{CO}_{2}$. Bacterial colonies were counted $24 \mathrm{~h}$ later and colony-forming units (CFUs) calculated. Criteria for infection were met when $\log 10$ of $\mathrm{CFU} / \mathrm{ml}$ exceeded 5.

Daily health score. Animal well-being was assessed daily in a detailed fashion throughout the experiment (for scoring criteria, see Hetze et al., 2013). Scores for each parameter (e.g., grooming, eye and nasal discharge, breathing, activity) ranged from 0 to 2 , where 0 indicates normal appearance and 2 major deficits. The maximum score possible was thus 16.

Modified experimental autoimmune encephalomyelitis (EAE) score. We observed mice showing gait alterations reminiscent of EAE. Therefore, mice were evaluated for the appearance and severity of these symptoms daily starting $7 \mathrm{~d}$ after MCAo until the end of the study on day 30 using modified EAE score (modified from Adelmann et al., 1995): 0, no disease; 0.5 , partial tail paralysis; 1.0 , complete tail paralysis; 1.5 , limb weakness without tail paralysis; 2.0 , limb weakness with tail paralysis; 2.5 , partial limb and tail paralysis; 3.0, complete limb paralysis; 3.5 , paraplegia; 4.0, quadriplegia. The gait behavior of mice was first observed on a smooth surface. Mice were then transferred onto metal grid to follow foot faults. Tail tone was assessed by holding the mouse by the scruff of the neck to examine a reflex of spontaneous tail raise.

CatWalk gait analysis. Gait impairments after stroke were assessed using CatWalk (Noldus Information Technology) automated computerassisted method as described in detail previously (Hetze et al., 2012). Before the acquisition of baseline values, mice were trained on the CatWalk system in three sessions (three runs each) on 3 consecutive days. Duration of compliant runs was $0.5-5.0 \mathrm{~s}$, speed variation $<60 \%$. Run interruptions were not accepted. Poststroke acquisitions were performed 10 and $30 \mathrm{~d}$ after MCAo. Stroke-sensitive individual paw and gait parameters were selected based on a previously published model (Hetze et al., 2012). Swing speed was normalized to overcome bias from individual run speed.

Electrophysiology. Electrical stimulation of the distal nerve triggers a motor response and a second voltage change, termed the F-wave, as a fraction of spinal motoneurons backfire to periphery (Fisher, 2007). Here, the mean latencies to F-wave and F-wave chronodispersion (difference between the shortest and longest F-wave latency within one animal) (Fisher, 2007) were measured before and $14 \mathrm{~d}$ after MCAo. Anesthesia was induced with $2.5 \%$ and maintained at $1.0 \%-1.5 \%$ isoflurane in $1 / 2$ mixture of $\mathrm{O}_{2} / \mathrm{N}_{2} \mathrm{O}$. Body temperature was controlled with a heating pad. Two pairs of needle electrodes were used: (1) reference and stimulation; and (2) reference and recording. Electrical stimulus was applied at the sciatic notch, and corresponding reference electrode was inserted subcutaneously into peritoneal cavity. Acquisition and nerve stimulation parameters were controlled with Medtronic KeyPoint Portable software version 5.11 (Medtronic; RRID:SciRes_000159). Single stimulation lasted $0.2 \mathrm{~s}$ at $1.2 \mathrm{~mA}$. Recording electrode was inserted into the muscle innervated by sciatic nerve and corresponding reference into a lower extremity. Surface electrode was used and moistened with $0.9 \% \mathrm{NaCl}$ to increase the signal-to-noise ratio.

Tissue harvesting. Mice were anesthetized with ketamine $(150 \mathrm{mg} / \mathrm{kg}$; Deltaselect $)$ and xylazine (15 mg/kg; Bayer Vital). Spleen and lymph nodes (cervical, mesenteric, inguinal, and lumbar) were removed, and animals were transcardially perfused with $20 \mathrm{ml}$ of ice-cold $0.9 \% \mathrm{NaCl}$ per mouse at 80 $\mathrm{cm}$ water height.

In experiments designed for immunological analysis (endpoint on day 7 or 14 after MCAo), brains were collected into complete RPMI 1640 medium (Biochrom AG), supplemented with 10\% FCS (FCS Gold; PAA Laboratories), $50 \mathrm{U} / \mathrm{ml}$ penicillin, $50 \mu \mathrm{g} / \mathrm{ml}$ streptomycin (Biochrom $\mathrm{AG})$, and $2 \mathrm{~mm}$ L-alanyl-L-glutamine (Biochrom AG), and processed immediately.

In experiments where the primary outcome was assessment of neurological outcome (endpoint on day 30 ), perfusion with $0.9 \% \mathrm{NaCl}$ was followed by perfusion with $20 \mathrm{ml}$ ice-cold $4 \%$ PFA (Sigma-Aldrich) in 0.1 $\mathrm{M}$ Sörensen buffer, $\mathrm{pH}$ 7.4. Brains and vertebral columns were collected into $4 \%$ PFA for $24 \mathrm{~h}$ after fixation. Thereafter the brains were incubated for $5 \mathrm{~d}$ in $30 \%$ sucrose $(\mathrm{D}(+)$-sucrose; Carl Roth) solution in PBS (PAA Laboratories) for cryoprotection and snap frozen using 2-methylbutan (Carl Roth). Vertebral columns were placed into 0.1 M PBS until decalcification. Bone structures were decalcified with a $24 \mathrm{~h}$ incubation in Osteosoft (Merck KGaA), and tissue was stored in 0.1 M PBS until paraffin-embedding using routine protocol. Paraffin-embedded tissue blocks were cut on a microtome (thickness $2-3 \mu \mathrm{m}$ ), and slices were collected for immunohistochemistry.

Cell isolation from brain, spleen, and lymph nodes. Before enzymelinked immunospot (Elispot) assay, the cerebellum was removed and brain tissue forced through a $70 \mu \mathrm{m}$ pore size cell strainer (BD Falcon) into complete RPMI 1640 medium. Mononuclear cells (MNCs) were isolated from the interface of 35\% and 70\% Easycoll gradient (Biochrom AG). MNCs were stained with Trypan Blue dye (Biochrom AG) and quantified under light microscope.

Spleens and lymph nodes (cervical, mesenteric, inguinal, and lumbar) were forced through a $100 \mu \mathrm{m}$ pore size cell strainer (BD Falcon) and washed with complete RPMI 1640 medium (or magnetic-activated cell sorting [MACS] buffer containing 2\% FCS in sterile PBS for MACS assay). Before the MACS assay, erythrocytes in spleen were lysed with $30 \mathrm{~s}$ incubation with distilled water. Splenocytes and lymphocytes were forced through a $40 \mu \mathrm{m}$ cell strainer (BD Falcon) and washed with complete RPMI 1640 medium (or MACS buffer). Splenocytes were quantified using automated CasyTon cell counter and analyzer system (Casy-Technology Innovatis AG, SciRes_000160) and lymphocytes on the Trypan blue method. 
A
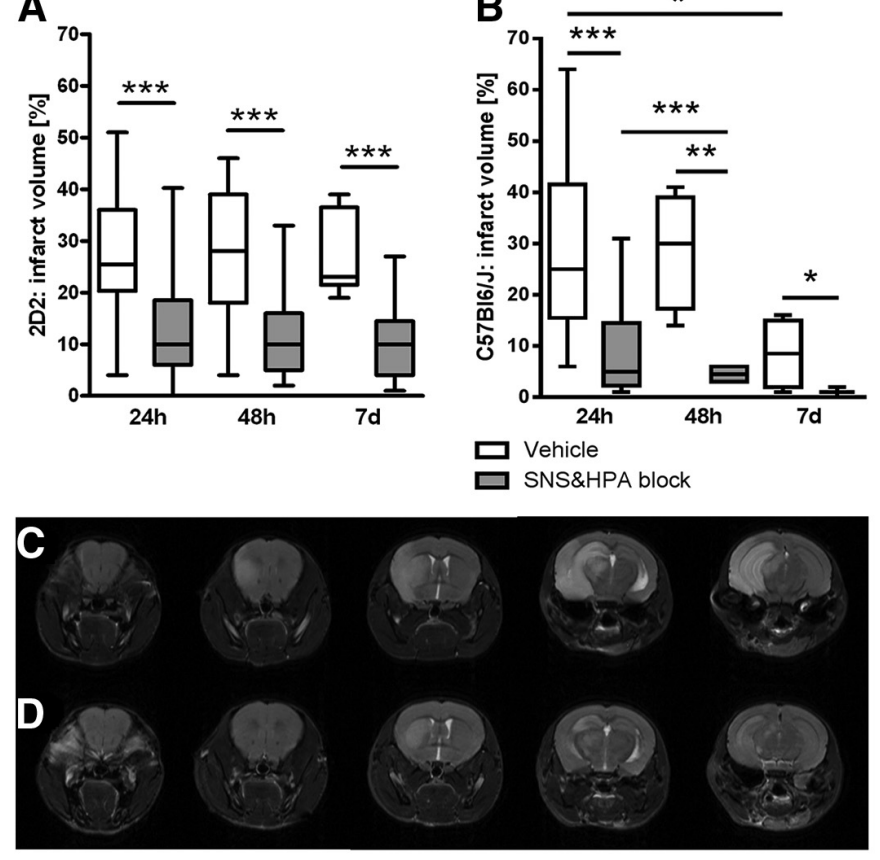

B

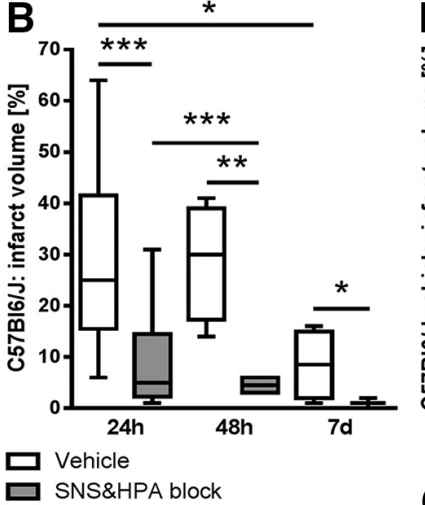

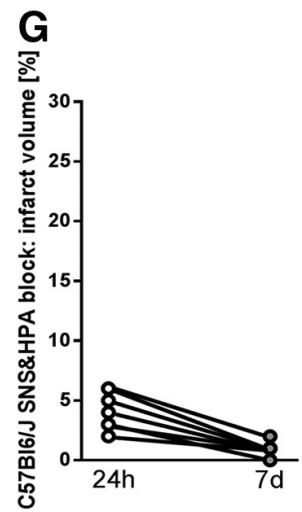
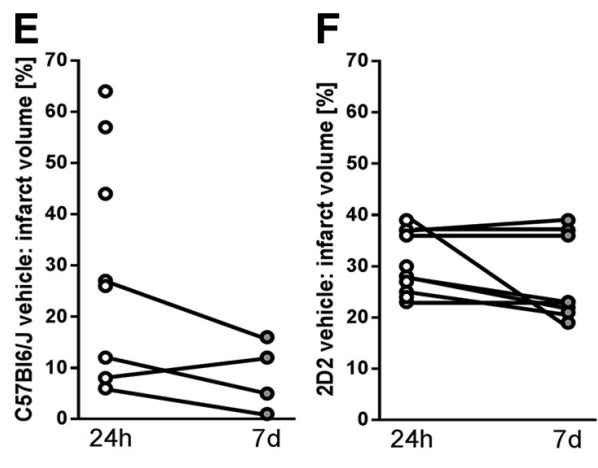

H

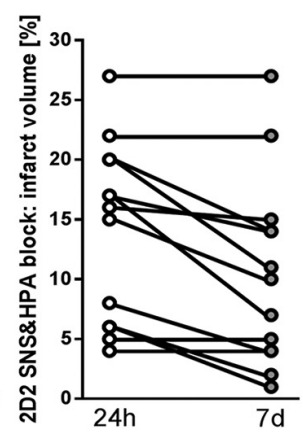

Figure 2. Infarct volumes were reduced after blocking SNS and HPA axis using propranolol and mifepristone. Ischemic lesions were smaller after SNS/HPA block in female $202 \mathrm{mice} 24 \mathrm{~h}$ (vehicle, $N=56 ;$ SNS/HPA block, $N=52$ ), $48 \mathrm{~h}$ (vehicle, $N=19 ; \mathrm{SNS} / \mathrm{HPA}$ block, $N=19$ ), and $7 \mathrm{~d}$ (vehicle, $N=8 ; \mathrm{SNS} / \mathrm{HPA}$ block, $N=13$ ) after MCAo $(A)$. Infarct volumes were $\sim 3$ times reduced at each time point (Student's test; at $24 \mathrm{~h}, t_{(106)}=6.3, p<0.0005 ;$ at $48 \mathrm{~h}, t_{(36)}=4.5, p<0.0005 ;$ at $\left.7 \mathrm{~d}, t_{(19)}=4.7, p<0.0005\right)$. Same effect was observed in $(57 \mathrm{BL} / 6 \mathrm{~J} \mathrm{mice} \mathrm{at} 24 \mathrm{~h}$ (vehicle, $N=25$; SNS/HPA block, $N=28$ ), $48 \mathrm{~h}$ (vehicle, $N=4 ; S N S / H P A$ block, $N=6$ ), and $7 \mathrm{~d}$ (vehicle, $N=4 ;$ SNS/HPA block, $N=7$ ) after MCAo (Mann-Whitney $U$ test; at $24 \mathrm{~h}, U=49.0, p<0.0005 ;$ at $48 \mathrm{~h}$, $U=0.0, p=0.010 ;$ at $7 \mathrm{~d}, U=3.5, p=0.021 ; \boldsymbol{B})$. Infarct volumes of vehicle-treated $\mathrm{C} 57 \mathrm{BL} / 6 \mathrm{~J}$ mice differed between $24 \mathrm{~h}$ and $7 \mathrm{~d}$ after MCAo (Mann-Whitney $U$ test; $U=10.0, p=0.020)$ and of propranolol- and mifepristone-treated mice between 24 and $48 \mathrm{~h}$ after MCAo (Mann-Whitney $U$ test; $U=18.5, p=0.001 ; \boldsymbol{B}$ ). T2-weighted images of ischemic lesions $24 \mathrm{~h}$ after MCA0 in vehicle-treated $(\boldsymbol{C})$ and SNS/HPA block $(\boldsymbol{D})$ group of mice. Lesions in vehicle-treated mice involved cortex, striatum, and hippocampus $(\boldsymbol{C})$, whereas those after SNS/HPA blockade comprised of multiple smaller ischemic foci rarely involving cortex $(\boldsymbol{D})$. Follow-up among surviving $(57 \mathrm{BL} / 6 \mathrm{~J}(\boldsymbol{E}, \boldsymbol{G})$ and $2 \mathrm{D} 2$ mice $(\boldsymbol{F}, \boldsymbol{H}) 24 \mathrm{~h}$ and $7 \mathrm{~d}$ after MCAo after vehicle treatment $(\boldsymbol{E})$ and SNS/HPA block treatment $(\boldsymbol{G})$ compared with $2 \mathrm{D2}$ mice $(\boldsymbol{F}$, vehicle treatment; $\boldsymbol{H}$, SNS/HPA block treatment). Infarct volume reduction within the vehicle and SNS/HPA block groups of $\mathrm{C57BL} / 6 \mathrm{~J}$ and $2 \mathrm{D2}$ mice between $24 \mathrm{~h}$ and $7 \mathrm{~d}$ after MCAo was similar. ${ }^{*} p<0.05 .{ }^{* *} p<0.01$. ${ }^{* * *} p<0.001$.

MACS assay, FACS, and cell transfer. Lymph nodes (cervical, mesenteric, inguinal, and lumbar) and spleens were collected from naive female 2D2 mice and from treated female 2D2 mice $7 \mathrm{~d}$ after the MCAo for an adaptive transfer experiment (see Fig. $1 B, C$ ). Cells were harvested as described above and pooled per group (naive, vehicle, SNS/HPA block). Untouched $\mathrm{CD} 4{ }^{+} \mathrm{T}$ cell sort was performed using $\mathrm{CD} 4{ }^{+} \mathrm{T}$ cell isolation kit for mice (Miltenyi Biotec) and LS columns (Miltenyi Biotec) according to the manufacturer's instructions. $\mathrm{CD} 4{ }^{+} \mathrm{T}$ cell purity was verified with FACS using APC-conjugated anti-CD4 monoclonal antibody (RM4-5; BD Biosciences, catalog \#553051 RRID:AB_398528). Samples were measured on FACSCalibur flow cytometer (BD Biosciences PharMingen; RRID:SciRes_000153) and analyzed with FlowJo software version 7.6.5. (Tree Star; RRID:nif-0000-30575). Sorted CD4 ${ }^{+} \mathrm{T}$ cells were characterized immunologically using FACS. Cells were resuspended in FACS buffer ( $2 \%$ FCS and $15.4 \mathrm{~mm}$ sodium azide in PBS) and centrifuged at $252 \times g$ at $4^{\circ} \mathrm{C}$ for $6 \mathrm{~min}$. Unspecific binding was blocked by incubation with anti-CD16/32 antibody $(2.4 \mathrm{G} 2$; BD Biosciences, catalog \#553141; RRID:AB_394656) at $4^{\circ} \mathrm{C}$ for $15 \mathrm{~min}$. Cellular surfaces were stained with following anti-mouse antibodies: APC-conjugated CD3 (145-2C11; eBioscience, catalog \#17-0031-82; RRID:AB_469315), Alexa-700-conjugated CD4 (RM4-5; eBioscience, catalog \#56-0042-82; RRID:AB_494000), APC-Cy7-conjugated CD44 (IM7; BD Biosciences, catalog \#560568; RRID:AB_1727481), biotin-conjugated TCR V $\alpha 3.2$ (RR3-16; BD Biosciences, catalog \#553218; RRID:AB_394714), PE-Cy7conjugated CD25 (PC61.5; eBioscience, catalog \#25-0251-82; RRID: AB_469608), Pacific blue-conjugated CD62L (MEL-14; BioLegend, catalog \#104424; RRID:AB_493380), PE-conjugated CD127 (SB/199; BD Biosciences, catalog \#552543; RRID:AB_394417), and FITC-conjugated
KLRG1 (2F1; eBioscience, catalog \#11-5893-82; RRID:AB_1311265). Samples were incubated with antibody mixtures light-protected on ice for $30 \mathrm{~min}$. Cell surfaces were stained in a second step for the detection of V 33.2 TCR receptor with biotin-binding PerCP-conjugated streptavidin (BD Biosciences PharMingen, catalog \#554064; RRID:AB_2336918). Samples were measured on an LSR II flow cytometer (BD Biosciences PharMingen; RRID:SciRes_000152) using FACSDiva software version 6.1.3 (BD Biosciences PharMingen, BD FACSDiva Software; RRID:SciRes_000115). Data were analyzed with FlowJo software version 7.6.5. The following cell populations were distinguished: V $\alpha 3.2^{+}$MOG-TCR transgenic $\mathrm{CD}^{+}{ }^{+} \mathrm{T}$ cells $\left(\mathrm{V} \alpha 3.2^{+} \mathrm{CD} 4{ }^{+} \mathrm{CD} 3^{+}\right)$, effector memory (MOG-specific) $\mathrm{T}$ cells $\left[\mathrm{CD} 62 \mathrm{~L}^{-} \mathrm{CD} 44^{+}\right.$from $\left(\mathrm{V} \alpha 3.2^{+}\right) \mathrm{CD}^{+}{ }^{+} \mathrm{CD} 3^{+}$ cell population], central memory (MOG-specific) $\mathrm{T}$ cells $\left[\mathrm{CD} 62 \mathrm{~L}^{+}\right.$ $\mathrm{CD} 44^{+}$from $\left(\mathrm{V} \alpha 3.2^{+}\right) \mathrm{CD}^{+} \mathrm{CD}^{+}$cell population], and regulatory (MOG-specific) T cells $\left[\mathrm{CD} 25^{+} \mathrm{CD}_{12} 7^{-}\right.$from $\left(\mathrm{V} \alpha 3.2^{+}\right) \mathrm{CD}^{+}{ }^{+} \mathrm{CD} 3^{+}$ cell population].

Two million untouched $\mathrm{CD} 4{ }^{+} \mathrm{T}$ cells were injected intravenously to corresponding gender-mixed Rag-1KO recipients $6 \mathrm{~h}$ after MCAo.

Elispot assay. Elispot assay was performed from brain MNCs and splenocytes of 2D2 mice harvested $14 \mathrm{~d}$ after MCAo. Brain MNC Elispot was performed from mice where only the SNS-mediated SIDS was blocked and the SNS- and HPA-mediated SIDSs were both simultaneously blocked. For this, Elispot plates (96-well plates with hydrophobic PVDF membrane, $0.45 \mu \mathrm{m}$ pore size; EMD Millipore) were coated overnight with $5 \mu \mathrm{g} / \mathrm{ml}$ of the following: (1) IFN- $\gamma$ (for Th1 cells; eBioscience, catalog \#14-7313-85; RRID:AB_468472); (2) IL-4 (for Th2 cells; BD Biosciences, catalog \#551878; RRID:AB_2336921); or (3) IL-17 (for Th17 cells; eBioscience, catalog \#16-7175-85; RRID:AB_763573) specific cap- 
A

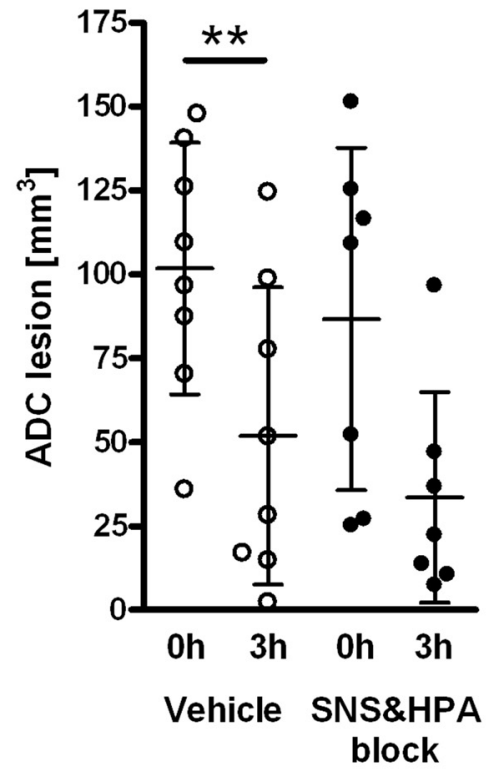

B

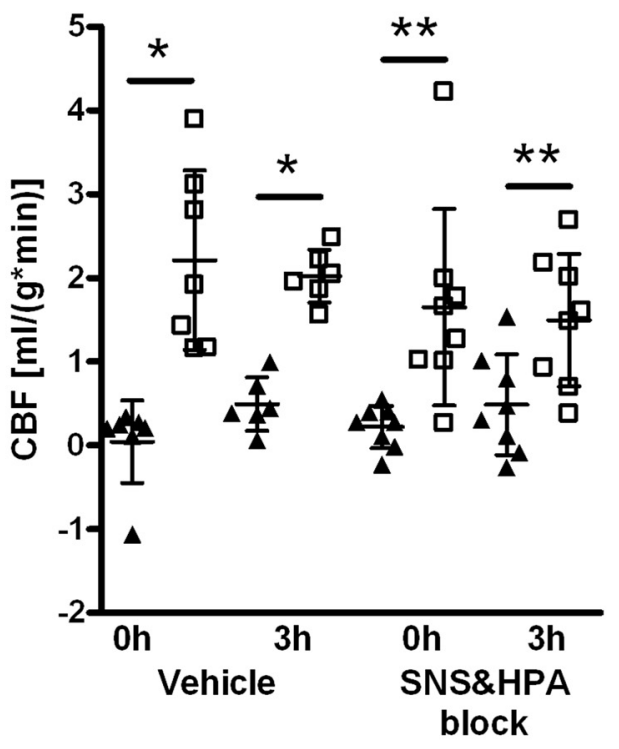

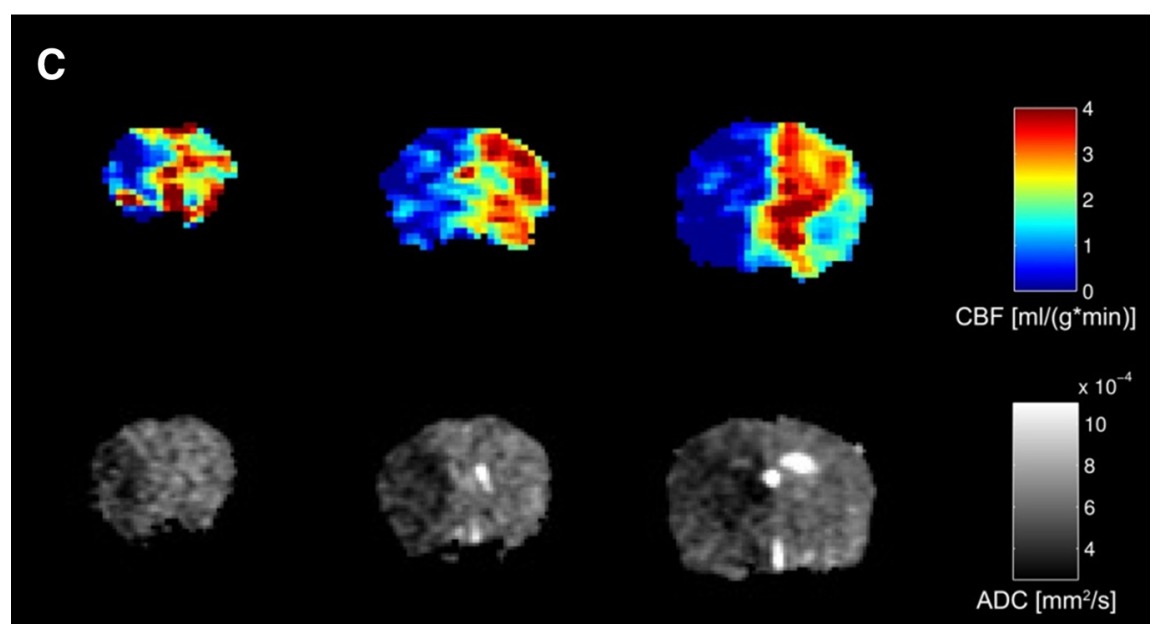

Figure 3. $C B F$, measured by FAIR-MRI, does not differ between vehicle and SNS/HPA block group at filament insertion and $3 \mathrm{~h}$ after MCA0. $A, A D C$ map lesion sizes were similar in vehicle and SNS/HPA block group immediately after MCAo (vehicle, $N=8$; SNS/HPA block, $N=7$ ) and $3 \mathrm{~h}$ after MCAo (vehicle, $N=8 ;$ SNS/HPA block, $N=7$ ). In the vehicle group of mice, lesions on $A D C$ maps decreased within $3 \mathrm{~h}$ after MCA0 (Wilcoxon test; $Z=-2.3, p=0.008$ ). $B$, Hemispheric CBF differed in both groups at each time point (Wilcoxon test; immediately after MCAo: vehicle, $Z=-2.4, p=0.016$, SNS/HPA block, $Z=-2.5, p=0.008 ; 3 \mathrm{~h}$ after MCAo: vehicle, $Z=-2.2, p=0.031$, SNS/HPA block, $Z=-2.5, p=0.008$ ) but not between the groups of interest [vehicle, $0 \mathrm{~h}$, $N=7 ; 3 \mathrm{~h}, N=6 ;$ SNS/HPA block, $0 \mathrm{~h}, N=8 ; 3 \mathrm{~h}, N=8$ ). C, FAIR-MRI (top row; for CBF evaluation) and ADC images (bottom row) from coronal sections (at $2 \mathrm{~mm}$ interval) from the same mouse with an index bar. ${ }^{*} p<0.05 .{ }^{* *} p<0.01$.

ture antibody in sterile PBS. Plates were washed with sterile PBS and blocked with $1 \%$ BSA fraction V (Sigma-Aldrich) in PBS for $2 \mathrm{~h}$ at room temperature. Wells were filled with $100 \mu \mathrm{l}$ of the following: (1) complete HL-1 medium (Lonza) supplemented with $2 \mathrm{~mm}$ L-alanyl-L-glutamine, $50 \mathrm{U} / \mathrm{ml}$ penicillin, and $50 \mu \mathrm{g} / \mathrm{ml}$ streptomycin, with $2 \mu \mathrm{g} / \mathrm{ml} \mathrm{CD}-3$ (145-2C11; eBioscience, catalog \#16-0031-86; RRID:AB_468849) and $0.2 \mu \mathrm{g} / \mathrm{ml} \mathrm{CD}-28$ (37.51; eBioscience, catalog \#14-0281-85; RRID: AB_467191); duplicates per sample (positive control); (2) complete HL- 1 medium with $0.2 \mu \mathrm{g} / \mathrm{ml} \mathrm{CD}-28$ and $40 \mu \mathrm{g} / \mathrm{ml}$ myelin oligodendrocyte glycoprotein peptide pMOG $_{35-55}$, amino acid sequence: MEVGWYRSPFSRVVHLYRNGK; a gift from Dr. Rudolf Volkmer; Charité Universitätsmedizin Berlin, Berlin, Germany); triplicates per sample ( $\mathrm{MOG}_{35-55}$-peptide stimulation); and (3) complete HL-1 medium with $0.2 \mu \mathrm{g} / \mathrm{ml} \mathrm{CD}-28$; triplicates per sample (negative control). In brain Elispot, brain MNCs were added at $1.75 \times 10^{5}$ in $50 \mu$ complete HL-1 medium per well together with $1 \times 10^{6}$ naive C57BL/6J splenocytes in $50 \mu \mathrm{l}$ complete HL-1 medium. In spleen Elispot, $3.75 \times 10^{5}(\mathrm{IFN}-\gamma)$ or $1 \times 10^{6}(\mathrm{IL}-4$ and IL-17) splenocytes were added in $100 \mu \mathrm{l}$ complete HL-1 medium per well. Cells were incubated at $37^{\circ} \mathrm{C}, 5 \% \mathrm{CO}_{2}$ for $24 \mathrm{~h}$ (IFN- $\gamma$ plates) or $48 \mathrm{~h}$ (IL-4 and IL-17 plates). Plates were washed with PBS and subsequently with PBS supplied with $0.05 \%$ Tween 20 (SigmaAldrich) before incubation with a biotinylated secondary antibody [IFN- $\gamma$ (eBioscience, cata$\log$ \#13-7311-81; RRID:AB_466936); IL-4 (BD Biosciences, catalog \#551878; RRID:AB 2336921); or IL-17 (eBioscience, catalog \#137177-85; RRID:AB_763571] in a solution of $0.05 \%$ Tween 20 and $1.5 \mathrm{~mm}$ BSA in PBS at $4^{\circ} \mathrm{C}$ overnight. Plates were washed with $0.05 \%$ Tween 20 in PBS. Secondary antibody binding was visualized with streptavidin-HRP (BD Biosciences PharMingen) and $50 \mathrm{~mm}$ 3-amino-9ethylcarbazole (Sigma-Aldrich) in $30 \mathrm{~mm}$ acetic acid glacial (Merck KGaA), 117 mm sodium acetate (Sigma-Aldrich), and $5 \mu \mathrm{M} \mathrm{H}_{2} \mathrm{O}_{2}$ (Merck KGaA). Formed spots were analyzed semiautomatically using ImmunoSpot software version 4.013 (Cellular Technology; RRID: SciRes_000119).

Multiplex immunoassay and ELISA for quantifying cytokine production from brain and spleen. Fourteen days after MCAo, braininfiltrating cells and splenocytes were isolated and stimulated as for Elispot assay. Cell culture supernatants were collected and stored at $-20^{\circ} \mathrm{C}$ until measurement. From each sample, $25 \mu \mathrm{l}$ supernatant was used for multiplex assay to quantify T cell-specific cytokine (IL-2, IL-4, IL-10, IL-17, and IFN- $\gamma$ ) production. Mouse multiplex kit (Millipore) and Human/Mouse TGF- $\beta 1$ ELISA Ready-SET-Go kit (Affymetrix) were used according to the manufacturer's recommendations. Plates were read at $450 \mathrm{~nm}$ by a Luminex Instrument (Bio-Plex 200 System and Bio-Plex Manager Software version 6.1; Dartmouth DartLab; RRID: SciEx_11307). For quantification of TGF- $\beta 1$ production, samples were acidified with $1 \mathrm{M}$ $\mathrm{HCl}$ to activate latent TGF- $\beta 1$ to immunoreactive form and then neutralized with $1 \mathrm{M}$ $\mathrm{NaOH}$. Each sample was measured once.

Histological analysis of nerve root damage and inflammation. Paraffin sections (2-3 $\mu \mathrm{m}$ thick) containing vertebral columns and nerve roots were routinely stained with hematoxylin and eosin for assessing inflammation and Luxol fast blue for assessing demyelination. Adjacent serial sections were used for immunohistochemistry. Antigen retrieval was done by cooking the slides in citrate ( $\mathrm{pH}$ 6.0) or EDTA buffer ( $\mathrm{pH} 8.5$; for V $\alpha 3.2$ TCR staining) for $1 \mathrm{~h}$ (both from Sigma-Aldrich). After cooling down and washing in PBS, slides were incubated overnight with primary antibodies raised against Mac3 (M3/84; host species rat; dilution 1/100; BD Biosciences, catalog \#553322; RRID:AB_394780) for macrophages and CD3 (SP7; host species rabbit; dilution 1/500; Lab Vision, catalog \#RM-9107-S1; RRID:AB_149924) for T cells. Axonal injury was visualized with $\beta$-amyloid precursor protein staining ( $\beta$-APP; host species mouse; dilution 1/500; Millipore, catalog \#MAB5228; RRID:AB_95173). Immunoreactivity to V $\alpha 3.2$ TCR was detected with biotin-conjugated V 23.2 TCR antibody (RR3-16; host species rat; dilution 1/100; BD Biosciences, catalog \#553218; RRID:AB_394714). All antibodies were diluted in 10\% FCS in PBS. Immunopositive structures were detected with biotin-avidin technique using 3,3'-diaminobenzidine-tetrahydrochloride 
(Sigma) as chromogen. Control sections were stained in the absence of primary antibody.

The cumulative area of spinal nerve cross sections $\left(\mathrm{mm}^{2}\right)$ within the decalcified vertebral columns and immunostained structures $\left(\mathrm{Mac}^{+}, \mathrm{CD}^{+}, \mathrm{APP}^{+}\right.$, and $\mathrm{V} \alpha 3.2^{+}$) were quantified under light microscope using an optical grid. All available nerve root cross sections were examined. Data are presented as numbers of immunopositive structures per $\mathrm{mm}^{2}$ nerve root.

Histological analysis of inflammation and infiltration of $\mathrm{CD}^{+} \mathrm{T}$ cells into the brain. Snapfrozen brains were cut into $30-\mu \mathrm{m}$-thick sections on a sliding microtome. After washing with Tris-buffered saline (TBS), free-floating sections were incubated with $10 \%$ normal goat serum (NGS, BIOZOL Diagnostica Vertrieb) and $0.3 \%$ Triton X (LABORAT) in TBS for $1 \mathrm{~h}$ at room temperature to block unspecific binding. Primary and secondary antibodies were diluted in $1 \%$ NGS and $0.3 \%$ Triton X in TBS. Sections were incubated with rat anti-CD4 primary antibody (clone RM4-5, BD Biosciences, catalog \#550280; RRID: AB_393575) for $\mathrm{CD}^{+} \mathrm{T}$ cells and rabbit anti-Iba-1 primary antibody (Wako Chemicals, catalog \#019-19741; RRID:AB_839504) for microglia and macrophages at $4^{\circ} \mathrm{C}$ overnight. After thorough washing, sections were incubated at room temperature with AlexaFluor-488conjugated goat anti-rat (Invitrogen, catalog \#A11006 RRID:AB_10561520) and AlexaFluor568-conjugated goat anti-rabbit (Invitrogen, cata$\log$ \#A11011 RRID:AB_10584650) secondary antibodies (both from Invitrogen) for $2 \mathrm{~h}$. Nuclei were counterstained with DAPI (Invitrogen). Sections were mounted with anti-fading mounting medium DABCO (Sigma-Aldrich) on gelatinized glass slides. Microphotographs were taken with a confocal microscope (Leica TCS SPE; RRID:SciRes_000154).

Quantification of CD4 ${ }^{+} \mathrm{T}$ cells, activated microglia, and macrophages was performed using a stereology workstation consisting of a fluorescence microscope (Leica DMRE Fluorescence Microscope; RRID:SciRes_000155) and Stereo Investigator software (MBF Bioscience; RRID:SciRes_000114). Hemispheres were outlined, and Meander scan was selected to count all positively stained cells within the ipsilateral hemisphere. Activated microglia/ macrophages were distinguished from resident resting microglia based on morphology and localization. Cell densities were calculated per $\mathrm{mm}^{2}$ ipsilateral hemisphere.

Statistical analysis. Data were analyzed with SPSS Statistics 21.0 software for Windows (IBM Somers; SPSS; RRID:rid_000042). Normality of data distribution was assessed with Kolmogorov-Smirnov test. $p$ values for parametric data were calculated with two-tailed Student's $t$ test or one-way ANOVA for multiple comparisons with Bonferroni correction where indicated. Nonparametric data were analyzed with Kruskal-Wallis (with pairwise Dunn's method were applicable) and Mann-Whitney $U$ test. Dependent samples with nonparametric distribution were analyzed using Wilcoxon signed rank test. Only exact two-tailed $p$ values were accepted for nonparametric tests. $\chi^{2}$ test was applied to evaluate survival differences between groups. $p$ value $<0.05$ was considered significant. Correlation analysis was performed using Spearman's $\rho$ correlation coefficient for nonparametric data and Pearson correlation coefficient for parametric data. Data are mean \pm SD. Health and EAE score are pre-
B
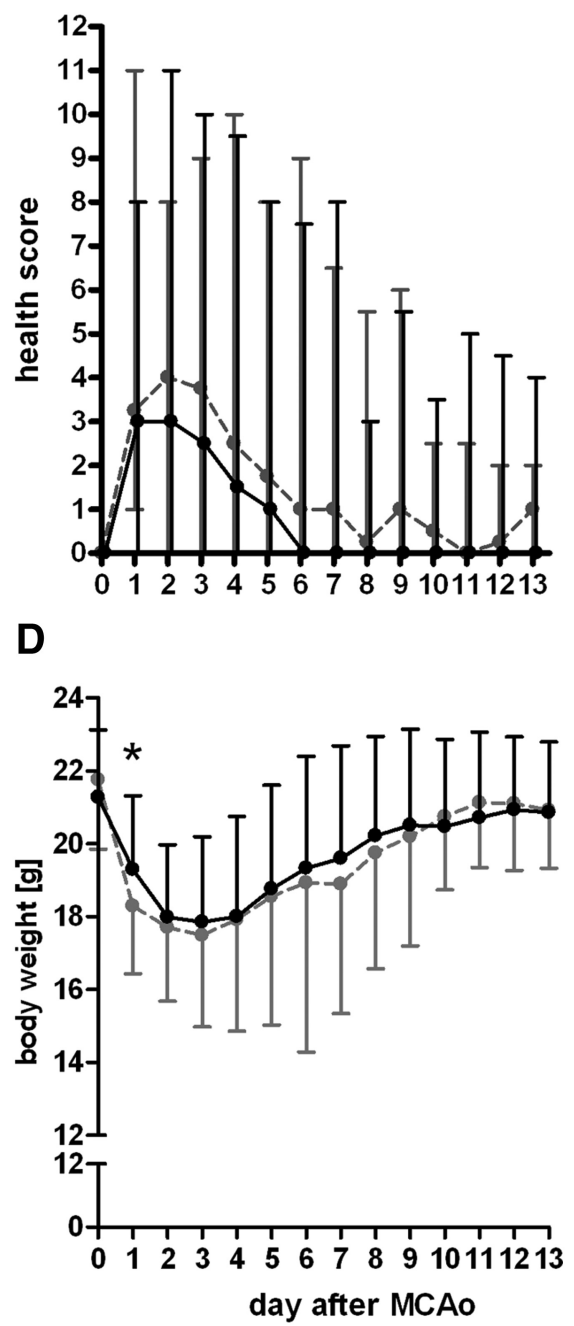

Figure 4. $2 D 2$ mice from stress axes blockade group show better long-term $(30 \mathrm{~d})$ survival and body temperature maintenance after experimental stroke. $\boldsymbol{A}$, Propranolol and mifepristone treatment improved survival until $30 \mathrm{~d}$ after MCAo compared with (Student's $t$ test, day 3: vehicle: $N=48 ;$ SNS/HPA block: $N=50 ; t_{(96)}=-2.5, p=0.015$; day 7: vehicle: $N=29 ;$ 9: vehicle: $N=26 ;$ SNS/HPA block: $N=41 ; t_{(65)}=-2.1, p=0.040 ;$ day 12: vehicle: $N=24 ;$ SNS/HPA block: $N=40 ; t_{(62)}=$ $-2.5, p=0.014)$. D, Body weight loss was overall similar in both groups (vehicle: $N=52$; SNS/HPA block: $N=52 ;$ day 2 : Student's $t$ test, $\left.t_{(102)}=-2.6, p=0.011\right)$. $\boldsymbol{B}$, Data are median \pm range. $\boldsymbol{C}, \boldsymbol{D}$, Data are mean $\pm S D .{ }^{*} p<0.05$.

sented as median \pm range. Survival data are plotted on Kaplan-Meier curve.

\section{Results}

Blockade of SNS and HPA reduced infarct volumes

To investigate the effect of SIDS on CNS antigen-specific autoreactivity, we used 2D2 transgenic mice. These mice are sensitive for investigating CNS antigen-specific immune responses because the majority of their $\mathrm{CD} 4{ }^{+} \mathrm{T}$ cells carry a functional receptor for MOG (Bettelli et al., 2003). SNS and the HPA axes both affect strongly cellular immunity and function mainly in an additive manner (Elenkov et al., 2000; Tischner and Reichardt, 2007). Therefore, to prevent SIDS efficiently, we blocked the SNS and HPA axis simultaneously using $\beta$-receptor blocker propranolol and glucocorticoid receptor antagonist mifepristone (Fig. 1A). 
A

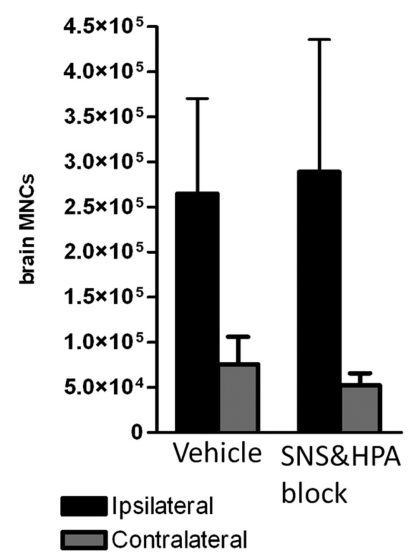

E

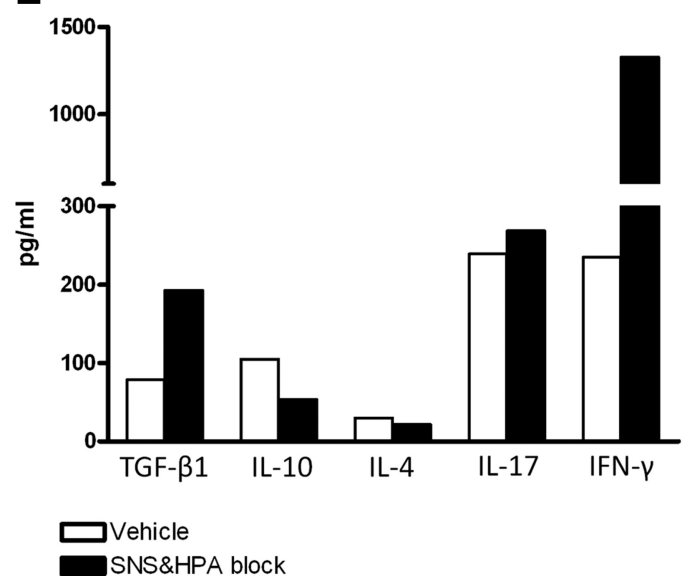

C
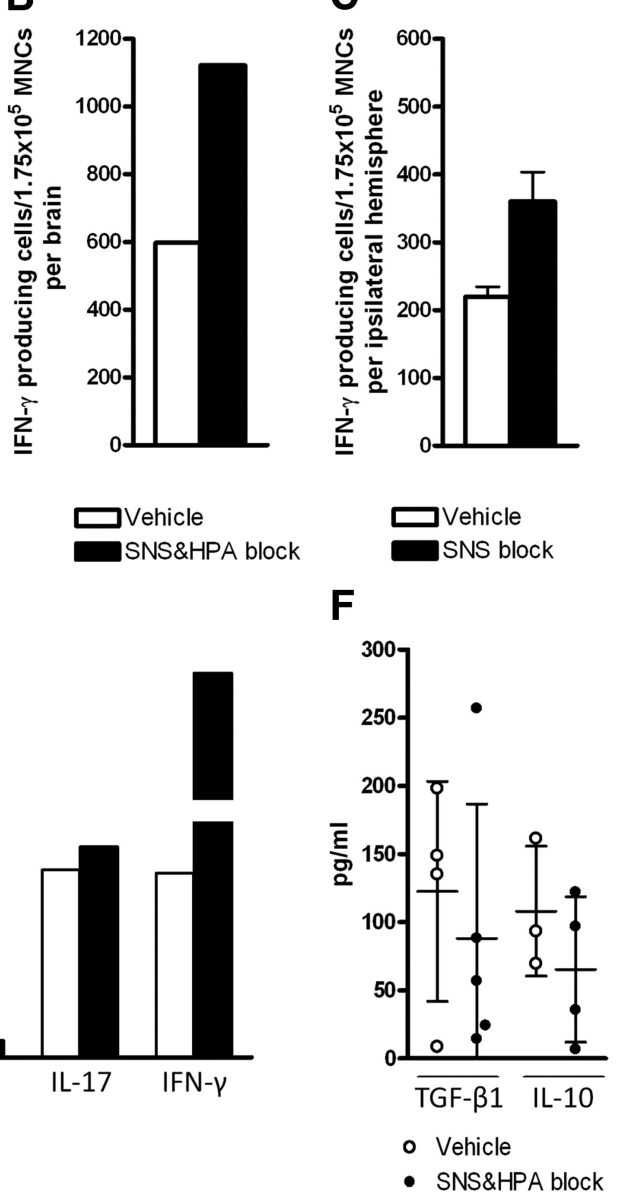

$\mathbf{F}$
- SNS\&HPA block

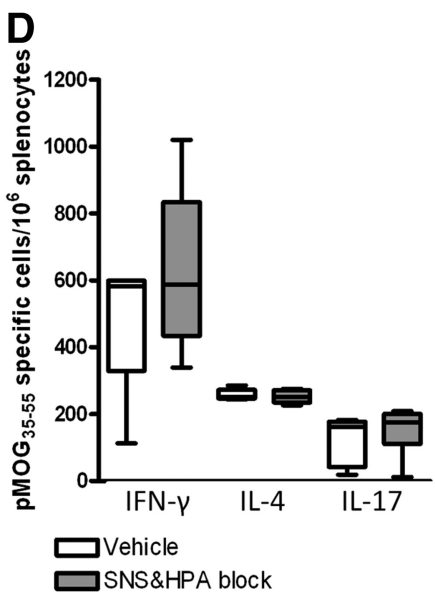

$\square$ SNS\&HPA block

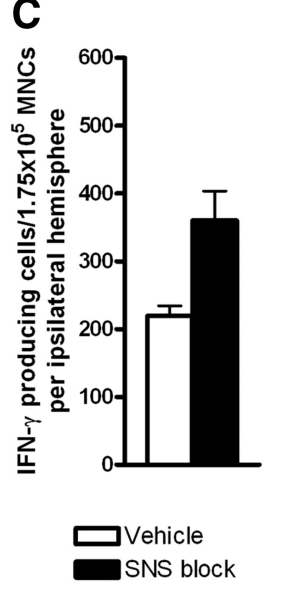

Figure 5. Number of brain MNCs and their CNS antigen-specific autoreactive phenotype $14 \mathrm{~d}$ after MCAo. $A$, Number of MNCs infiltrating ipsilateral and contralateral hemisphere of the brain in vehicle and SNS/HPA blockade group (three individual experiments; vehicle, $N=15 ;$ SNS/HPA block, $N=20$ ). $\boldsymbol{B}-\boldsymbol{D}$, Elispot experiments. $\boldsymbol{B}$, Higher number of total brain MNCs responded to $\mathrm{pMOG}_{35-55}$ stimulation with IFN- $\gamma$ production (Th1 cells) per equal number of brain MNCs in SNS/HPA block group compared with the vehicle group. $C$, A similar effect was observed in ipsilateral hemisphere MNCs when only the SNS axis of SIDS was blocked with propranolol (two experiments; vehicle group, $N=5-8 ;$;NS block, $N=6$ or 7 ). $D$, Number of splenocytes reacting to $p M O G_{35-55}$ stimulation with IFN- $\gamma$, IL-4, or IL-17 secretion did not differ between the groups. E, $F$, ELISA experiments. TGF- $\beta 1$, IL-10, IL-4, IL-17, and IFN- $\gamma$ secretion (pg/ml) by pMOG ${ }_{35-55}$-stimulated brain MNCs, ipsilateral hemisphere $(\boldsymbol{E})$ and by $\mathrm{pMOG}_{35-55}$-stimulated splenocytes $(\boldsymbol{F})$.

Dual blockade of stress axes with propranolol and mifepristone resulted in significantly smaller infarct volumes compared with vehicle treatment (Fig. 2A). Approximately three times smaller infarct volumes were sustained for at least 1 week after stroke onset (measurements were performed at $24 \mathrm{~h}, 48 \mathrm{~h}$, and $7 \mathrm{~d}$ after MCAo). Combined treatment effect of propranolol and mifepristone is therefore sustained and not explained by mere delayed infarct volume maturation.

To exclude mouse strain-specific effects, we next investigated the effect of stress axes blockade on infarct volume in wild-type C57BL/6J mice. In accordance with the data from 2D2 mice, SNS/HPA blockade resulted in a robust reduction of infarct volumes (Fig. 2B).

Ischemic lesions in vehicle-treated mice affected striatum, hippocampus, and cortex. Lesions in mice with SNS/HPA blockade involved the cortex only rarely. Another difference between the groups was the uniformly large ischemic lesion in the vehicle group compared with the combination of small focal lesions in mice with SNS/HPA blockade (Fig. 2C,D).

The dynamic changes in ischemic lesion were investigated in surviving wild-type C57BL/6J (Fig. 2E, G) and 2D2 (Fig. 2F,H) mice $24 \mathrm{~h}$ and $7 \mathrm{~d}$ after MCAo. In surviving animals, the ischemic lesions tended to be smaller in C57BL/6J mice compared with
2D2 mice from both vehicle and SNS/HPA block groups (Fig. $2 E-H)$. However, average reduction in ischemic lesion size within $7 \mathrm{~d}$ after MCAo was similar between C57BL/6J ( $-4.8 \pm$ $6.3 \%)$ and $2 \mathrm{D} 2(-4.1 \pm 7.0 \%)$ mice from vehicle as well as from SNS/HPA block group (C57BL/6J, $-3.1 \pm 1.4 \% ; 2 D 2,-3.6 \pm$ $3.4 \%)$.

\section{Reduction of infarct volume by SIDS blockade was not due to} altered CBF

The most straightforward cause for reduced infarct size is increased CBF because it relates inversely with lesion size after cerebral ischemia (Dalkara et al., 1994). To investigate whether the observed infarct volume reduction was due to altered CBF by SNS/HPA blockade, we performed FAIR-MRI combined with DWI in 2D2 and C57BL/6J mice immediately after filament insertion to the MCA and again $3 \mathrm{~h}$ after MCAo surgery (Fig. 3). DWI lesions did not differ significantly between the groups (Fig. $3 A$ ). During cerebral ischemia sustained by MCAo, a large lesion on ADC map was observed ipsilaterally that shrank $2 \mathrm{~h}$ after reperfusion. The size of this lesion did not differ between treatment groups (Fig. $3 A$ ). Hemispheric CBF was greatly reduced ipsilateral to MCAo in all groups but was not affected by stress blockade either $0 \mathrm{~h}$ or $3 \mathrm{~h}$ after stroke onset (Fig. $3 B, C$ ). 


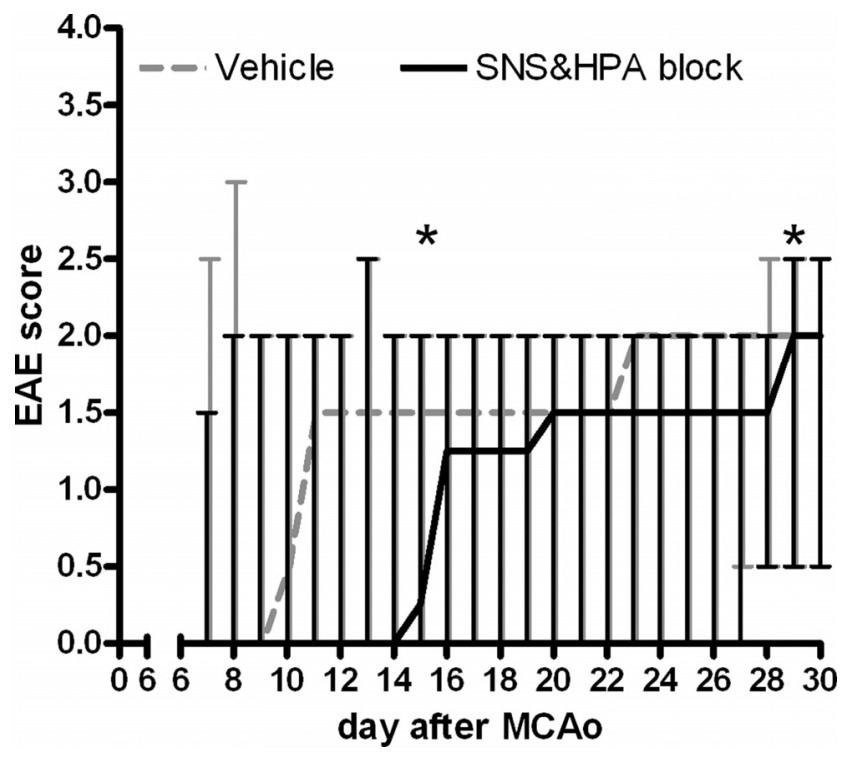

Figure 6. EAE-like symptoms were not affected by SNS/HPA block, compared with vehicle treatment. Modified EAE score in vehicle-treated and SNS/HPA blocked 202 mice 7-30 d after experimental stroke. $2 D 2$ mice developed EAE-like symptoms in median on day 9 (vehicle group, $N=21$ ) and day 14 (SNS/HPA block group, $N=31$ ). Data are expressed as median \pm range. ${ }^{*} p<0.05$.

Differences between the CBF and its dynamics within the $3 \mathrm{~h}$ after MCAo were similar in both groups ipsilaterally and contralaterally.

\section{Blocking stress axes improved long-term survival and temperature maintenance of mice}

In addition to decreasing infarct volume, propranolol and mifepristone treatment improved survival of 2D2 mice until the end of the observation period $30 \mathrm{~d}$ after MCAo (Fig. 4A). Compared with only $52 \%$ of mice surviving in the vehicle group, the longterm survival of mice with SNS/HPA blockade was 73\%.

Although mice from the SNS/HPA block group did not differ statistically from vehicle-treated mice in terms of general health score (Fig. 4B) and had only minor differences in body weight (Fig. 4D), they were better at maintenance of body temperature (Fig. 4C).

In a post hoc analysis of vehicle-treated $2 \mathrm{D} 2$ mice, we compared smaller $(<20 \% ; N=14)$ with larger edema-corrected infarct volumes $(>20 \% ; N=39)$. Survival of mice with smaller lesions over the $30 \mathrm{~d}$-follow-up after stroke was better (86\%) compared with mice with larger lesions $\left(43 \% ; \chi^{2}=5.1, \mathrm{df}=1\right.$, $p=0.024)$. Health status measured by general health score was better in mice with smaller infarct volumes from day 2 through day 5 after experimental stroke (Student's $t$ test; on day $2, t_{(35)}=$ $3.6, p=0.010$; on day $3, t_{(36)}=3.2, p=0.030$; on day $4, t_{(32)}=$ $3.7, p=0.001$; on day $5, t_{(28)}=2.3, p=0.032$ ), accompanied by better maintenance of body temperature on day 2 to day 4 as well as on day 11 after stroke (Student's $t$ test; on day $2, t_{(47)}=-4.8$, $p<0.0005$; on day $3, t_{(46)}=-2.7, p=0.009 ; t_{(39)}=-2.3, p=$ $\left.0.025 ; t_{(22)}=-2.6, p=0.018\right)$. Body weight loss between the groups did not differ significantly (data not shown).

\section{Blocking stress axes promoted recovery from infections}

Many hypothermic mice in the vehicle group died $4 \mathrm{~d}$ after MCAo (Fig. 4A), reminiscent of severe poststroke infections, such as bacterial pneumonia (Prass et al., 2003; Meisel et al., 2004). To verify this, $2 \mathrm{D} 2$ mice (vehicle, $N=11$, SNS/HPA block,
$N=14$ ) were examined by BAL for bacterial burden in lung $3 \mathrm{~d}$ after MCAo. The overall infection rate following preventive enrofloxacin treatment was low in both groups. However, mice with SNS/HPA blockade with pulmonary infections (CFU/ml BAL fluid $>$ LOG(10) 5) recovered or survived longer than those from the vehicle group (vehicle, $N=4$; SNS/HPA block, $N=5 ; \chi^{2}=$ $7.6, \mathrm{df}=1, p=0.006$; data not shown).

\section{Blocking SIDS increased the CNS antigen-specific T-cell response in ischemic brain $14 \mathrm{~d}$ after MCAo}

Infiltration of CD4 ${ }^{+} \mathrm{T}$ cells into ischemic brain peaks $14 \mathrm{~d}$ after MCAo (Stubbe et al., 2013). Hence, we chose this time point to follow immune cell infiltration and CNS antigen-specific T-cell responses to investigate whether inhibition of SIDS by SNS/HPA blockade affects CNS-directed autoreactivity in ischemic brain. The average number of ipsilateral and contralateral hemisphereinfiltrating MNCs $14 \mathrm{~d}$ after MCAo was similar in the vehicle and SNS/HPA blockade group of 2D2 mice (Fig. 5A).

To investigate the CNS antigen-specific autoreactivity of brain-infiltrating MNCs, we performed an Elispot assay to quan-

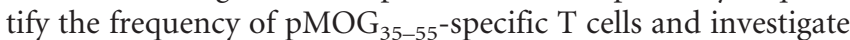
their cytokine profile. SNS/HPA blockade increased the frequency of $\mathrm{MNCs}$ responding to $\mathrm{pMOG}_{35-55}$ with IFN- $\gamma$ secretion from 598 per $3.25 \times 10^{5}$ total brain MNCs in vehicle-treated mice to 1122 per $3.25 \times 10^{5}$ of total brain MNCs (Fig. $5 B$ ). Despite similar numbers of MNCs infiltrating ischemic brain after MCAo, a higher number of total brain MNCs responded to $\mathrm{pMOG}_{35-55}$ stimulation with IFN- $\gamma$ production in SNS/HPA blockade compared with the vehicle group of 2D2 mice (Fig. 5). These findings support our hypothesis that inhibiting SIDS by SNS/HPA blockade increases CNS antigen-specific Th1 cell response of brain-infiltrating MNCs. When blocking only the SNS but not the HPA axis, the difference in the frequency of MOGspecific autoreactive Th1 cells among ipsilateral hemisphereinfiltrating MNCs became smaller between the SNS block (360 per $1.75 \times 10^{5}$ ipsilateral hemisphere brain MNCs) and the vehicle group $\left(220\right.$ per $1.75 \times 10^{5}$ ipsilateral hemisphere brain MNCs) (Fig. 5C), suggesting an additive function of the SNS and the HPA axis in preventing the autoreactive T-cell responses after acute brain injury. We measured multiple cytokines (IL-4, IL-10, IL-17, IFN- $\gamma$, TGF- $\beta 1$ ) from ex vivo MOG stimulated braininfiltrating cells by multiplex immunoassay and ELISA. Corroborating our data from Elispot analysis, we observed an upregulation of IFN- $\gamma$ production in the SNS/HPA blocked group compared with the vehicle group. In addition to autoreactive Th1 responses, we analyzed the production of multiple cytokines, including regulatory cytokines, TGF- $\beta 1$, and IL-10, upon MOG stimulation in brain MNCs of 2D2 mice $14 \mathrm{~d}$ after MCAo using ELISA. Whereas IL-10 production was reduced in SNS/ HPA blockade compared with vehicle groups of mice, TGF- $\beta 1$ levels upon MOG stimulation were increased in the SNS/HPA block group of mice (Fig. 5E).

Next, we questioned whether increase in autoreactive T-cell responses after SIDS blockade in stroke animals was confined to the CNS. For this, we harvested splenocytes $14 \mathrm{~d}$ after MCAo and quantified the number of IFN- $\gamma$ (Th1 cell signature cytokine), IL-4 (Th2 cell signature cytokine), and IL-17 (Th17 cell signature cytokine) secreting cells after $\mathrm{pMOG}_{35-55}$ stimulation by Elispot assay and regulatory-type cytokine production by ELISA. Blocking SIDS with propranolol and mifepristone did not change the numbers of Th1, Th2, or Th17 effector cytokine-producing cells or the amount of TGF- $\beta 1$ and IL-10 secretion by $\mathrm{pMOG}_{35-55^{-}}$ stimulated splenocytes significantly (Fig. $5 D, F$ ). Ratios between 
Table 1. Dynamic changes in gait parameters measured 10 and $30 \mathrm{~d}$ after MCAo in $2 D 2$ mice belonging to vehicle (day $10, N=21 ;$ day $30, N=14$ ) and SNS/HPA block group (day $10, N=29 ;$ day $30, N=19$ ) and their comparison with baseline values $(N=108)$ before $M_{C} A_{0}{ }^{a}$

\begin{tabular}{|c|c|c|c|c|c|c|c|}
\hline \multirow[b]{2}{*}{$2 D 2$ mice: parameter } & \multirow[b]{2}{*}{ Definition } & \multirow[b]{2}{*}{ Paw } & \multirow[b]{2}{*}{ Baseline } & \multicolumn{2}{|l|}{ Vehicle (mean $\pm S D$ ) } & \multicolumn{2}{|l|}{ SNS/HPA block (mean \pm SD) } \\
\hline & & & & Day 10 & Day 30 & Day 10 & Day 30 \\
\hline \multicolumn{8}{|l|}{ Spatial characteristics } \\
\hline \multirow[t]{4}{*}{ Maximal contact area $\left(\mathrm{mm}^{2}\right)$} & \multirow{4}{*}{$\begin{array}{c}\text { Area of a paw print at } \\
\text { maximal walking } \\
\text { surface contact }\end{array}$} & RF & $26.25 \pm 13.82$ & $16.70 \pm 7.306\left({ }^{* *} p=0.003\right)$ & $15.53 \pm 6.801\left({ }^{* *} p=0.005\right)$ & $16.42 \pm 5.730\left({ }^{* * *} p<0.0005\right)$ & $18.00 \pm 6.306\left({ }^{*} p=0.025\right)$ \\
\hline & & $\mathrm{RH}$ & $19.82 \pm 14.68$ & $12.92 \pm 6.435$ & $13.99 \pm 8.764$ & $11.79 \pm 5.158\left({ }^{*} p=0.012\right)$ & $15.51 \pm 6.447\left({ }^{\#} p=0.042\right)$ \\
\hline & & LF & $26.89 \pm 14.05$ & $19.00 \pm 5.348\left({ }^{*} p=0.026\right)$ & $18.77 \pm 5.564$ & $18.79 \pm 6.448(* * p=0.006)$ & $21.59 \pm 6.505$ \\
\hline & & LH & $19.73 \pm 14.06$ & $14.51 \pm 5.684$ & $17.42 \pm 9.744$ & $15.51 \pm 8.000$ & $22.00 \pm 10.09\left({ }^{\#} p=0.024\right)$ \\
\hline \multicolumn{8}{|l|}{ Kinetic characteristics } \\
\hline Run duration (s) & $\begin{array}{l}\text { Time for passing the } \\
\text { walkway }\end{array}$ & & $2.120 \pm 0.562$ & $2.798 \pm 0.664(* * * p<0.0005)$ & $2.666 \pm 0.539\left({ }^{*} p=0.040\right)$ & $2.559 \pm 0.683\left({ }^{*} p=0.031\right)$ & $2.759 \pm 0.564\left({ }^{* *} p=0.002\right)$ \\
\hline \multirow[t]{4}{*}{ Normalized swing speed (mm) } & \multirow{4}{*}{$\begin{array}{l}\text { Swing speed } \times \text { run } \\
\text { duration }\end{array}$} & RF & $1167 \pm 235.4$ & $998.9 \pm 212.5$ & $939.4 \pm 186.9\left(^{*} p=0.013\right)$ & $973.0 \pm 258.5(* * p=0.005)$ & $931.1 \pm 179.5\left({ }^{* *} p=0.002\right)$ \\
\hline & & $\mathrm{RH}$ & $983.8 \pm 242.4$ & $820.2 \pm 185.0\left({ }^{*} p=0.050\right)$ & $804.3 \pm 197.9$ & $791.7 \pm 194.1(* * p=0.003)$ & $778.2 \pm 223.7(* * p=0.007)$ \\
\hline & & LF & $1168 \pm 233.6$ & $1073 \pm 177.2$ & $1001 \pm 238.0$ & $1008 \pm 228.4\left({ }^{*} p=0.032\right)$ & $967.4 \pm 216.3\left(^{*} p=0.013\right)$ \\
\hline & & LH & $992.3 \pm 235.8$ & $912.7 \pm 230.9$ & $906.5 \pm 272.1$ & $881.8 \pm 255.9$ & $882.0 \pm 234.7$ \\
\hline \multirow[t]{4}{*}{ Stand (s) } & \multirow{4}{*}{$\begin{array}{l}\text { Duration of a paw contact } \\
\text { with walking surface }\end{array}$} & RF & $0.137 \pm 0.033$ & $0.161 \pm 0.048$ & $0.164 \pm 0.054$ & $0.156 \pm 0.049$ & $0.172 \pm 0.039\left(^{*} p=0.037\right)$ \\
\hline & & $\mathrm{RH}$ & $0.115 \pm 0.033$ & $0.132 \pm 0.039$ & $0.138 \pm 0.046$ & $0.131 \pm 0.041$ & $0.142 \pm 0.041$ \\
\hline & & LF & $0.140 \pm 0.031$ & $0.166 \pm 0.039$ & $0.170 \pm 0.044$ & $0.162 \pm 0.043$ & $0.176 \pm 0.041(* * p=0.008)$ \\
\hline & & LH & $0.114 \pm 0.032$ & $0.146 \pm 0.041\left(^{*} p=0.036\right)$ & $0.154 \pm 0.052$ & $0.140 \pm 0.047\left({ }^{*} p=0.018\right)$ & $0.163 \pm 0.041(* * * p<0.0005)$ \\
\hline \multicolumn{8}{|l|}{ Comparative statistics } \\
\hline Regularity index (\%) & Regularity of gait & & $92.01 \pm 7.358$ & $87.91 \pm 18.94$ & $93.13 \pm 4.871$ & $88.34 \pm 14.22$ & $93.41 \pm 5.221$ \\
\hline \multirow[t]{2}{*}{ Base of support (mm) } & \multirow[t]{2}{*}{ Distance between paws } & RF-LF & $7.928 \pm 5.334$ & $10.06 \pm 5.463$ & $14.19 \pm 8.221\left(*^{*} p=0.042\right)$ & $12.77 \pm 8.814\left({ }^{*} p=0.045\right)$ & $13.26 \pm 7.772$ \\
\hline & & RH-LH & $14.26 \pm 9.701$ & $20.16 \pm 12.49$ & $28.33 \pm 15.53\left({ }^{*} p=0.014\right)$ & $26.26 \pm 17.40(* * p=0.005)$ & $27.04 \pm 16.87\left({ }^{*} p=0.012\right)$ \\
\hline \multirow[t]{2}{*}{ Print positions (mm) } & \multirow{2}{*}{$\begin{array}{l}\text { Distance of a hindpaw } \\
\text { position to previous } \\
\text { position of front paw }\end{array}$} & RF-RH & $9.567 \pm 3.970$ & $8.856 \pm 3.953$ & $8.716 \pm 5.010$ & $9.004 \pm 3.519$ & $9.221 \pm 3.555$ \\
\hline & & LF-LH & $11.38 \pm 5.321$ & $9.589 \pm 4.481$ & $7.380 \pm 4.413$ & $10.42 \pm 4.587$ & $8.311 \pm 4.095$ \\
\hline \multirow[t]{4}{*}{ Stride length (mm) } & \multirow{4}{*}{$\begin{array}{l}\text { Distance between succes- } \\
\text { sive steps with one } \\
\text { paw }\end{array}$} & $\mathrm{RF}$ & $63.88 \pm 9.181$ & $50.63 \pm 17.19\left({ }^{* *} p=0.006\right)$ & $48.94 \pm 15.76\left({ }^{* *} p=0.008\right)$ & $50.19 \pm 17.06\left({ }^{* * *} p=0.001\right)$ & $47.82 \pm 14.02\left({ }^{* * *} p=0.001\right)$ \\
\hline & & $\mathrm{RH}$ & $60.60 \pm 8.631$ & $46.11 \pm 18.55\left({ }^{* *} p=0.008\right)$ & $47.50 \pm 17.36$ & $53.62 \pm 21.15$ & $43.92 \pm 13.39(* * p=0.002)$ \\
\hline & & LF & $64.25 \pm 8.651$ & $48.94 \pm 16.65(* * * p=0.001)$ & $50.13 \pm 16.35\left({ }^{*} p=0.012\right)$ & $51.13 \pm 16.95\left({ }^{* * *} p=0.001\right)$ & $47.22 \pm 13.09(* * * 0<0.0005)$ \\
\hline & & LH & $58.37 \pm 10.93$ & $45.78 \pm 16.57\left({ }^{* *} p=0.010\right)$ & $48.35 \pm 17.09$ & $46.78 \pm 15.37(* * p=0.008)$ & $45.48 \pm 12.75(* * p=0.011)$ \\
\hline \multirow[t]{6}{*}{ Phase dispersions (\%) } & \multirow{6}{*}{$\begin{array}{l}\text { Contact of a target paw in } \\
\text { relation to step cycle } \\
\text { of the anchor paw }\end{array}$} & RF-LH & $6.663 \pm 7.276$ & $9.099 \pm 7.519$ & $1.815 \pm 9.420$ & $6.526 \pm 6.815$ & $2.952 \pm 4.866$ \\
\hline & & LF-RH & $5.535 \pm 5.437$ & $7.898 \pm 6.963$ & $5.380 \pm 6.284$ & $4.049 \pm 6.621$ & $7.249 \pm 7.746$ \\
\hline & & LH-RH & $42.65 \pm 8.210$ & $44.10 \pm 10.07$ & $44.96 \pm 7.445$ & $42.69 \pm 8.282$ & $44.08 \pm 7.502$ \\
\hline & & LF-RF & $49.45 \pm 3.765$ & $50.25 \pm 3.931$ & $51.76 \pm 3.799$ & $47.88 \pm 7.821$ & $50.94 \pm 4.265$ \\
\hline & & RF-RH & $50.66 \pm 5.702$ & $49.11 \pm 11.09$ & $49.40 \pm 6.656$ & $49.90 \pm 8.948$ & $48.90 \pm 5.527$ \\
\hline & & LF-LH & $48.34 \pm 6.634$ & $50.45 \pm 4.274$ & $49.27 \pm 6.122$ & $48.06 \pm 5.767$ & $49.21 \pm 6.429$ \\
\hline
\end{tabular}

${ }^{a}$ Gait alterations in 202 mice (vehicle and SNS/HPA block groups) 10 and $30 \mathrm{~d}$ after MCAo. RF, Right forepaw; RH, right hindpaw; LF, left forepaw; LH, left hindpaw.

${ }^{*} p<0.05 ;{ }^{* *} p<0.01 ;{ }^{* * *} p<0.001$ (one-way ANOVA with Bonferroni correction). ${ }^{*}$ Compared with baseline values. ${ }^{*}$ Compared with day 10 SNS/HPA block.

pMOG $_{35-55}$-specific Th1 and Th2 (vehicle group, $1.97 \pm 0.77$; SNS/HPA blockade group, $2.50 \pm 0.88)$ and Th17 and Th1 cells (vehicle group, $0.24 \pm 0.08$; SNS/HPA blockade group, $0.28 \pm$ 0.19 ) were similar in both groups.

The total number of splenocytes $14 \mathrm{~d}$ after MCAo did not differ significantly between vehicle $\left(N=6,1.0 \times 10^{8} \pm 4.4 \times\right.$ $\left.10^{7}\right)$ and the SNS/HPA block group $\left(N=9,1.4 \times 10^{8} \pm 6.1 \times\right.$ $\left.10^{7}\right)$. Compared with naive $2 \mathrm{D} 2$ splenocytes $\left(N=10,5.5 \times 10^{8}\right.$ $\pm 4.3 \times 10^{8}$ ), this number was reduced in both groups (one-way ANOVA, $F_{(2)}=7.0$ : naive vs vehicle: $p=0.014$; naive vs SNS/ HPA block: $p=0.013$; data not shown).

\section{Blocking SIDS did not augment EAE-like symptoms and locomotor deficits}

We next investigated whether increased autoreactive immune responses in ischemic brain after blocking SIDS were associated with worse functional outcome. Mice recover from sensorimotor deficits typically within 1 week after MCAo. Whereas stroke affects immediately and predominantly the contralateral side and in particular the contralateral forepaw, we observed a progressive and ascending paralysis affecting the tail and limbs of both sides symmetrically beginning from 1 week after MCAo. This phenotype observed in 2D2 mice is reminiscent of EAE. Therefore, we applied the modified EAE score starting assessment from day 7 after MCAo. Interestingly, EAE score of 2D2 mice $30 \mathrm{~d}$ after MCAo correlated positively with infarct volume $24 \mathrm{~h}$ after MCAo among vehicle-treated $(N=11$, Spearman-Rho correlation coefficient $0.665, p=0.026$ ) but not mifepristone/propranolol- treated mice $(N=18$, Spearman $\rho$ correlation coefficient $=$ $0.089, p=0.726$ ). These findings suggest that EAE-like phenotype depends on ischemic lesion size and SIDS. Following experimental stroke, the majority of 2D2 mice from vehicle (87\%) and SNS/HPA block groups (91\%) developed EAE-like symptoms within the $30 \mathrm{~d}$ observation period. Median disease onset in mice after SNS/HPA blockade on day 14 was compared with day 9 in the vehicle group (Fig. 6). Additionally to applying modified EAE score, gait parameters were assessed using the semiautomated CatWalk gait analysis system.

Previously, we have identified sensitive gait parameters typically affected by stroke in male C57BL/6J mice (Hetze et al., 2012). Here, stroke mice from vehicle and SNS/HPA block groups displayed typical alterations in spatial and kinetic characteristics of gait without significant differences between the groups (Table 1).

Together, SIDS blockade boosted CNS antigen-specific immune response in the brain but, compared with vehicle treatment, did not worsen functional long-term outcome measured by modified EAE score or gait analysis.

\section{Blocking SIDS reduced immune cell infiltration into spinal nerve roots}

In the long-term course and beyond the initial hemiparesis after experimental stroke, 2D2 mice suffered from paralysis affecting hindpaws and tail. Hence, we hypothesized myelitis caused by CNS antigen-specific immune cell infiltration into the spinal cord. To investigate this phenomenon, we performed immuno- 

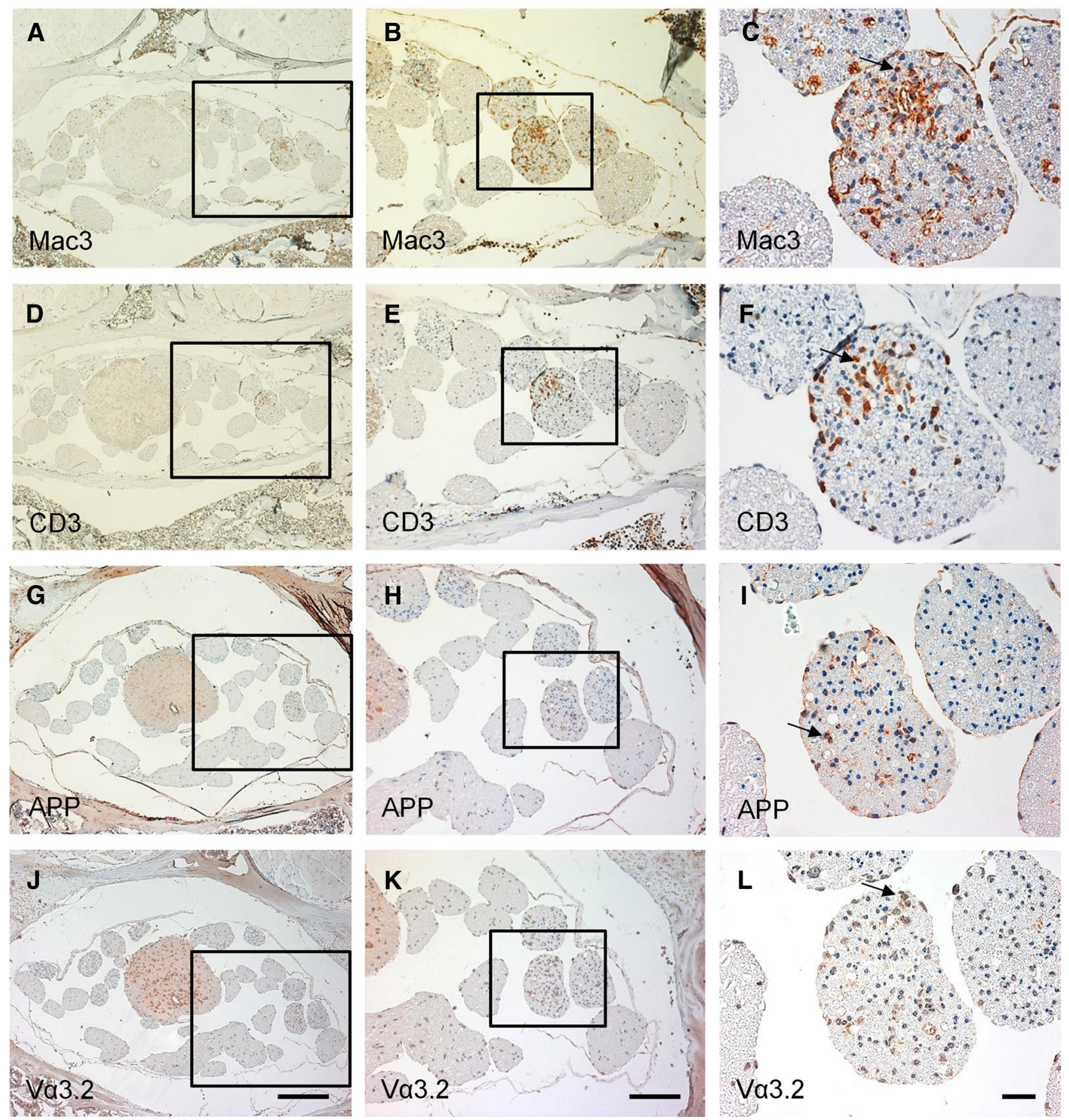

Figure 7. Representative immunohistochemistry demonstrating infiltration of $\mathrm{MaC}^{+}{ }^{+}$macrophages and $\mathrm{CD} 3^{+} \mathrm{T}$ cells, $\mathrm{APP}{ }^{+}$inflamed axons, and V $\alpha 3.2^{+} 2 \mathrm{D2} \mathrm{TCR}$-expressing $\mathrm{T}$ cells in the spinal nerve roots of $2 \mathrm{D} 2$ mice. Mac3 $(\boldsymbol{A}), \mathrm{CD} 3(\boldsymbol{D}), \mathrm{APP}(\boldsymbol{G})$, and $\mathrm{V} \alpha 3.2(J)$ staining of the spinal cord in conjunction with nerve roots at sacral level where most of the cauda equina locates. Areas outlined in $\boldsymbol{A}, \boldsymbol{D}, \boldsymbol{G}$, and $\boldsymbol{J}$ are zoomed in $\boldsymbol{B}, \boldsymbol{E}, \boldsymbol{H}$, and $\boldsymbol{K}$ and $\boldsymbol{C}, \boldsymbol{F}, \boldsymbol{I}$, and $\boldsymbol{L}$, respectively. $\boldsymbol{C}, \boldsymbol{F}, \boldsymbol{I}, \boldsymbol{L}$, Arrows indicate immunostained cells (Mac3, CD3, V $\alpha 3.2)$ and axons (APP). There is increased cellular infiltration in single nerve roots, whereas many remain infiltrate-free. Scale bars: $A, D, G, J, 200 \mu \mathrm{m} ; B, E, H, K, 100 \mu \mathrm{m} ; C, F, I, L, 20 \mu \mathrm{m}$.

histochemical analysis of the vertebral columns containing nerve roots removed from $2 \mathrm{D} 2$ mice $30 \mathrm{~d}$ after MCAo. Tissue was stained for macrophages $\left(\mathrm{Mac}^{+}\right)$, T cells $\left(\mathrm{CD}^{+}\right)$, inflammatory axons $\left(\mathrm{APP}^{+}\right)$, and MOG-specific T cells $\left(\mathrm{V} \alpha 3 \cdot 2^{+}\right)$. No immune cells were found in the spinal cord. Surprisingly, immune cells had infiltrated into the spinal nerve roots (Fig. 7 ). CD ${ }^{+}$T cells were typically found in close vicinity of $\mathrm{Mac}^{+}$macrophages.

Average density (cells $/ \mathrm{mm}^{2}$ ) of $\mathrm{Mac}^{+}$and $\mathrm{CD} 3^{+}$cells was significantly higher in the nerve roots of vehicle-treated mice
(Fig. 8A). The average infiltration of MOG-specific T cells into the spinal nerve roots did not differ significantly between the groups (Fig. $8 B$ ), suggesting a considerable recruitment of nontransgenic $\mathrm{T}$ cells into the lesions of vehicle-treated mice. $\mathrm{APP}^{+}$-inflamed axons appeared at similar density in vehicle and SNS/HPA blockade groups. Spinal nerve roots revealed immunohistochemical signs of polyradiculitis at $14 \mathrm{~d}$ after MCAo also in wild-type C57BL/6J mice, however, without significant differences between the vehicle and SNS/HPA block groups (Fig. 8C). Infarct size $24 \mathrm{~h}$ after 
A

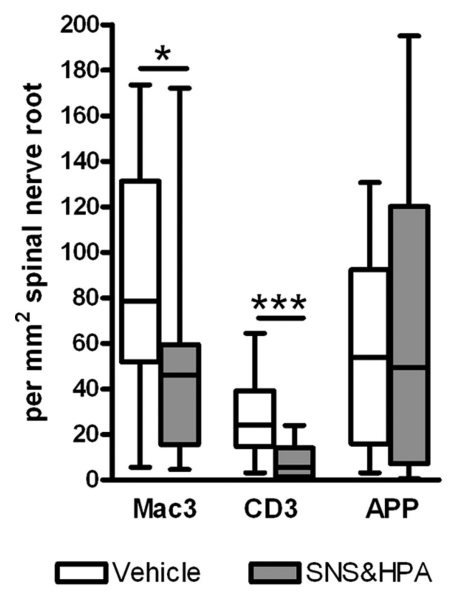

B

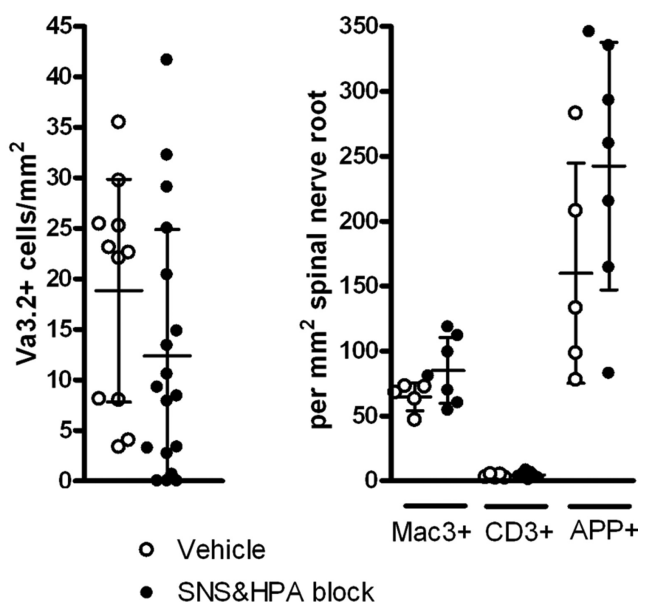

Figure 8. Blocking SIDS in 2D2, but not in $\mathrm{C} 57 \mathrm{BL} / 6 \mathrm{~J}$, mice diminished infiltration of $\mathrm{MaC} 3^{+}$and $\mathrm{CD} 3^{+}$cells into the spinal nerve roots. $A$, Numbers of $\mathrm{MaC}^{+}{ }^{+}, \mathrm{CD}^{+}{ }^{+}$, and $\mathrm{APP}^{+}$structures per $\mathrm{mm}^{2}$ nerve root. Densities of Mac3 ${ }^{+}$(Mann-Whitney $U$ test; $U=$ $51.0, p=0.031$ ) and $\mathrm{CD}^{+}{ }^{+}$cells (Mann-Whitney $U$ test; $U=27.0, p=0.001$ ) were reduced in the nerve roots of mice from the SNS/HPA block group $(N=18)$ compared with the vehicle-treated mice $(N=11) 30 \mathrm{~d}$ after experimental stroke. $B$, The number of $\mathrm{V} \alpha 3.2^{+}$cells in the nerve roots of $2 \mathrm{D} 2$ mice at the same time point did not differ significantly between the groups. $C, \ln C 57 \mathrm{BL} / 6 \mathrm{~J}$ mice $14 \mathrm{~d}$ after $\mathrm{MCA}$, the numbers of $\mathrm{MaC}^{+}{ }^{+}, \mathrm{CD}^{+}{ }^{+}$, and $\mathrm{APP}^{+}$structures per $\mathrm{mm}^{2}$ spinal nerve root did not differ between the groups. ${ }^{*} p<0.05 .{ }^{* * *} p<0.001$.

MCAo did not correlate with any immunohistochemical marker of polyradiculitis, either in 2D2 or in wild-type C57BL/6J mice (data not shown).

\section{SIDS blockade abolished elongation of sciatic nerve F-wave} latencies after experimental stroke in 2D2 mice

The phenotype of paralysis accompanied by infiltration of immune cells into the spinal nerve roots was rather flaccid than spastic and thus resembled the clinical characteristics of polyradiculitis. We aimed at characterizing this condition further and measured sciatic nerve conduction velocities to indirectly evaluate damage to myelin sheath around peripheral nerves and neuromuscular function. We measured F-wave latencies and chronodispersion in 2D2 mice upon sciatic nerve stimulation $14 \mathrm{~d}$ after MCAo (Fig. 9A, C). Latencies to F-wave were longer in vehicle-treated mice compared with baseline and SNS/HPA block group values (Fig. 9B). F-wave latencies of animals with SNS/HPA blockade remained at baseline, suggesting that SIDS blockade impeded elongated F-wave latencies after experimental stroke in 2D2 mice. Chronodispersion of F-waves did not differ significantly between treatment groups and was in the range of the baseline values (Fig. 9D).

Findings from electrophysiology and immunohistochemistry suggest, that following experimental stroke, 2D2 mice developed a disease phenotype reminiscent of polyradiculitis. Blocking stress axes diminished inflammation of the spinal nerve roots.

\section{Adoptive transfer of $2 \mathrm{D} 2 \mathrm{CD} 4{ }^{+} \mathrm{T}$ cells to $\mathrm{Rag}-1 \mathrm{KO}$ mice suggests that blockade of SIDS does not further aggravate EAE-like and polyradiculitis-like symptoms or performance on CatWalk gait analysis}

The experiments described above demonstrated that inhibiting stress axes to block SIDS reduces infarct volume and boosts CNS antigen-specific autoreactive immune responses in the brain. Because both effects are potentially opposing concerning functional outcome, lack of differences between the vehicle and SNS/HPA block groups does not necessarily exclude that blockade of SIDS influences long-term outcome of stroke detrimentally. In an attempt to prove whether autoreactive immune response has detrimental effects on long-term outcome after stroke, we needed to exclude the bias introduced by the protective effect of stress blockade with propranolol and mifepristone on infarct volume.

To address this issue, we performed an adoptive transfer experiment using 2D2 mice as donors and Rag-1 KO mice lacking functional $\mathrm{B}$ and $\mathrm{T}$ cells as recipients. Influences of spontaneous poststroke infections on outcome were minimized with preventive antibiotic use. Two million $\mathrm{CD}^{+} \mathrm{T}$ cells were harvested from the spleens and lymph nodes of 2D2 donor mice from the vehicle or SNS/HPA block groups $7 \mathrm{~d}$ after MCAo and transferred intravenously to Rag-1KO recipients $6 \mathrm{~h}$ after MCAo (Fig. 1 $B, C$ ). For a control, Rag-1KO mice received $\mathrm{CD}^{+}{ }^{+} \mathrm{T}$ cells from naive $2 D 2$ mice that were not treated, except from antibiotics, and were also not subjected to MCAo. Based on donors, Rag-1KO mice were divided into three groups, transferred with splenocytes and lymphocytes from the naive, vehicle, or SNS/HPA block group of 2D2 mice.

To characterize the cellular composition of lymphocytes for adoptive transfer experiments we analyzed MACS-sorted CD4 ${ }^{+}$ T cells isolated from lymph nodes (cervical, mesenteric, inguinal, lumbar) and splenocytes from donor $2 \mathrm{D} 2$ naive $(N=3)$, vehicletreated $(N=6)$, and mifepristone/propranolol-treated mice $(N=5) 7 \mathrm{~d}$ after MCAo using FACS. The number of MOG-TCRspecific $\mathrm{CD} 4{ }^{+} \mathrm{T}$ cells was similar in all three groups. The vehicletreated group had less MOG-specific effector memory $\left(\mathrm{CD} 44^{+}\right.$ $\left.\mathrm{CD}_{2} \mathrm{~L}^{-}\right)$and central memory $\mathrm{T}$ cells $\left(\mathrm{CD} 44^{+} \mathrm{CD}^{-\mathrm{L}^{+}}\right)$compared with naive 2D2 mice. Vehicle and SNS/HPA block groups of mice had similar numbers of MOG-specific effector and central memory T cells. The total numbers of effector memory T cells were lower in the vehicle group compared with the SNS/HPA block group of mice. The percentage of regulatory $\mathrm{T}$ cells among (MOG-specific) $\mathrm{CD} 4{ }^{+} \mathrm{T}$ cells was not different between the three groups (Fig. 10).

Rag-1KO mice from all three treatment groups developed equally large infarcts measured $24 \mathrm{~h}$ after MCAo (Fig. 11A). Therefore, a neuroprotective effect of blocking stress axes with propranolol and mifepristone was apparently not conveyed by adoptively transferred $2 \mathrm{D} 2 \mathrm{CD} 4{ }^{+} \mathrm{T}$ cells. Time course of body weight and rectal temperature was similar in all groups of $\mathrm{Rag}-1 \mathrm{KO}$ mice (Fig. $11 B, C$ ).

EAE-like disease symptoms tended to be less severe in all three transfer groups of Rag-1 KO mice compared with 2D2 mice (Figs. $6,12 A$ ) and were developed by $90 \%$ of the naive group, $89 \%$ of the vehicle group, and 78\% of the SNS/HPA block group of reconstituted Rag-1KO mice. Thus, EAE-like symptoms in Rag$1 \mathrm{KO}$ mice from the SNS/HPA block group were not aggravated by SIDS blockade in donor 2D2 mice. Consistent with less pronounced neurological deficits in comparison with 2D2 mice, the gait of Rag-1KO recipients after MCAo was not significantly altered, and mice from all three groups performed similarly on CatWalk (data not shown). 
These findings were corroborated by electrophysiology where sciatic nerve conduction velocities in recipient Rag$1 \mathrm{KO}$ mice from all three groups did not differ. Fourteen days after MCAo, F-wave latencies as well as chronodispersion remained at baseline in naive, vehicle, and SNS/HPA block group (Fig. 12 B, C).

In line with milder EAE-like disease in Rag-1KO mice, immunohistochemical analysis of spinal nerve roots revealed $\sim 4$ times lower frequencies of $\mathrm{CD}^{+}$and $\mathrm{Mac}^{+}$cells and $\mathrm{APP}{ }^{+}$inflamed axons in Rag-1KO mice $30 \mathrm{~d}$ after MCAo compared with 2D2 mice (Figs. 8, 12D). The three groups of Rag-1KO mice did not differ regarding the densities of $\mathrm{CD} 3^{+}$cells, $\mathrm{Mac}^{+}$macrophages, and $\mathrm{APP}{ }^{+}$axons in the spinal nerve roots.

Thirty days after MCAo, the transferred CD $4^{+} \mathrm{T}$ cells were still present in the brains of Rag-1KO mice. They accumulated mainly in the peri-infarct area (Fig. $13 A, D, G, J$ ), whereas activated Iba- ${ }^{+}$microglia/macrophages infiltrated both into infarct and peri-infarct regions (Fig. $13 B, E, H, K$ ). The relative densities of $\mathrm{CD}^{+}{ }^{+} \mathrm{T}$ cells and Iba- $1^{+}$activated microglia/macrophages in the brains of Rag-1KO mice $30 \mathrm{~d}$ after MCAo did not differ between the three transfer groups (Fig. 13C). Upon migrating toward the ischemic core, ramified resting microglia (Fig. 13F) had adopted amoeboid-like morphology with thickened processes. In ischemic lesion, their somata appeared irregular or oval (Fig. 13I) and cells were observed extravagating through enlarged blood vessels (Fig. 13L).

Lymphocyte-deficient Rag-1KO mice undergoing MCAo develop EAE-like symptoms following transfer of $\mathrm{CD}^{+}{ }^{+} \mathrm{T}$ cells from naive, vehicle-treated, and SIDSblocked 2D2 mice. Dual blocking of SNS and HPA mediated SIDS in donor mice does not further aggravate EAE-like symptoms, performance on CatWalk, or increase the number of CD4 ${ }^{+}$ $\mathrm{T}$ cell or Iba- $1^{+}$activated microglia/macrophages in ischemic brains in recipient mice compared with vehicle treatment. Neurological and functional deficits, including EAE-like symptoms, gait deficits, and immune cell infiltration to spinal cord, were lower in Rag-1KO mice after adoptive transfer than in 2D2 mice.

\section{Discussion}

Stroke induces hyperactivation of stress pathways, including the HPA and the SNS, leading to a rapid and long-lasting systemic suppression of cell-mediated immune responses causing spontaneous systemic bacterial infections within the first days after stroke (for review, see Meisel et al., 2005; Chamorro et al., 2012; Vogelgesang et al., 2014). The biological function of SIDS remains elusive. According to our main hypothesis, SIDS presents an adaptive response preventing autoreactive CNS antigenspecific immune responses after cerebral ischemia (Meisel et al., 2005; Dirnagl et al., 2007). We demonstrate here that preventing SIDS by inhibiting the body's main stress axes SNS and HPA
B

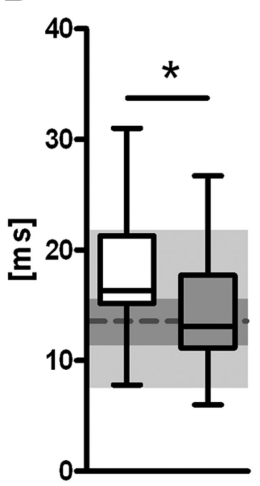

D

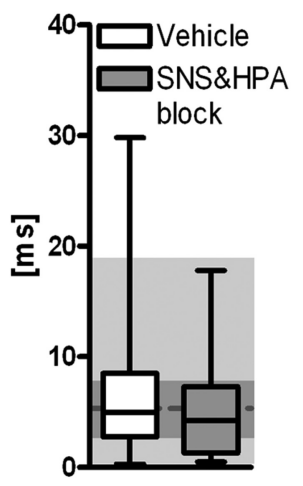

Figure 9. Increased F-wave latencies upon sciatic nerve stimulation in 202 mice after experimental stroke were normalized by blocking SIDS. $\boldsymbol{A}$, Baseline F-wave latency (amplitude in $\mathrm{mV}$ vs time in ms). $\boldsymbol{B}, 202$ mice from the vehicle group $(N=24)$ had

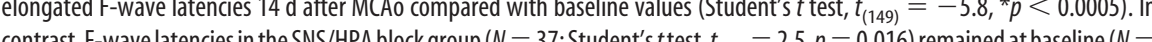
percentiles. Light gray rectangle represents range between minimum and maximum values. C, Delayed F-wave. D, F-wave chronodispersion remained at baseline in both groups of $2 \mathrm{D} 2$ mice.

increases delayed MOG-specific autoreactive CD4 ${ }^{+}$T-cell responses in the brains of MOG TCR transgenic 2D2 mice but does not worsen functional long-term outcome after experimental stroke.

After cerebral ischemia, the disruption of the blood-brain barrier allows leukocytes, including neutrophils, macrophages, and lymphocytes, to enter the damaged brain tissue and brain antigens to enter peripheral circulation. This process may expose brain epitopes, which are normally "invisible" to the immune system and thus promote priming and activation of lymphocytes reactive to the CNS antigens after stroke (Becker et al., 2005). Patients with cerebral ischemia were shown to have elevated antibody titers as well as increased numbers of circulating $\mathrm{T}$ cells specific for CNS antigens compared with age-matched healthy controls, indicating that inflammatory processes in the damaged CNS tissue may indeed induce self-directed immune responses (Bornstein et al., 2001; Dambinova et al., 2003). Depletion of circulating T-cell populations, which is a key mechanism of SIDS (Prass et al., 2003), reduces ischemic brain damage in experimental models of stroke (Kleinschnitz et al., 2010). While increasing the number of CNS antigen-specific Th1 cells in the brain, SNS/ HPA blockade reduced levels of IL-10, which is mainly produced by regulatory T cells. TGF- $\beta 1$, a further regulatory type cytokine, 


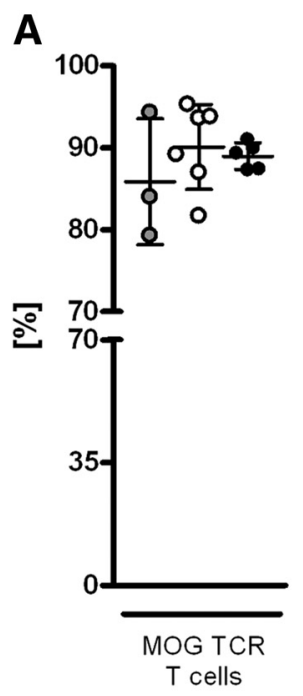

B

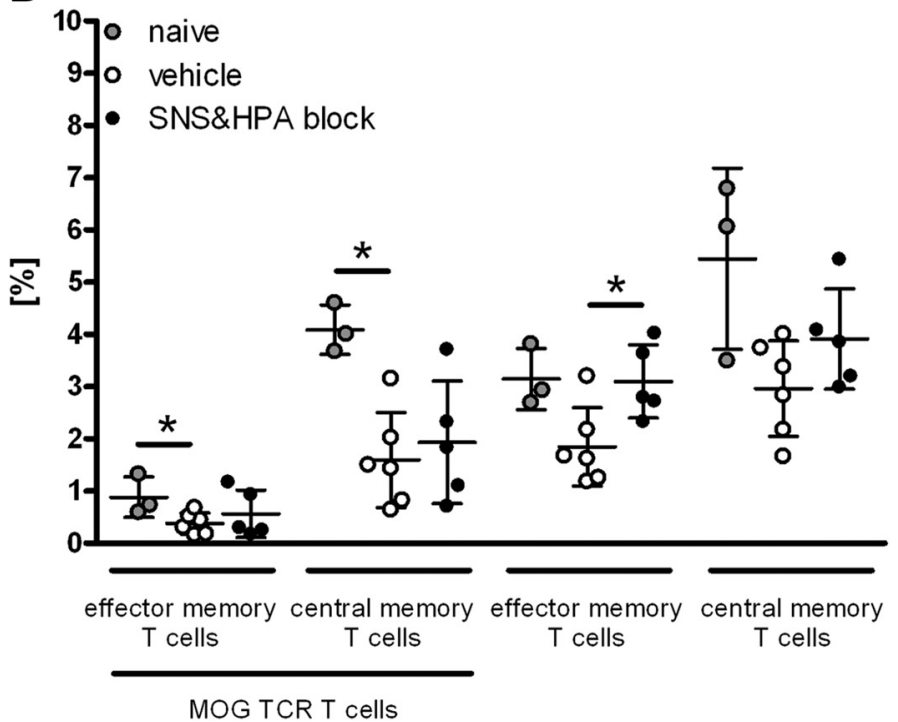

C

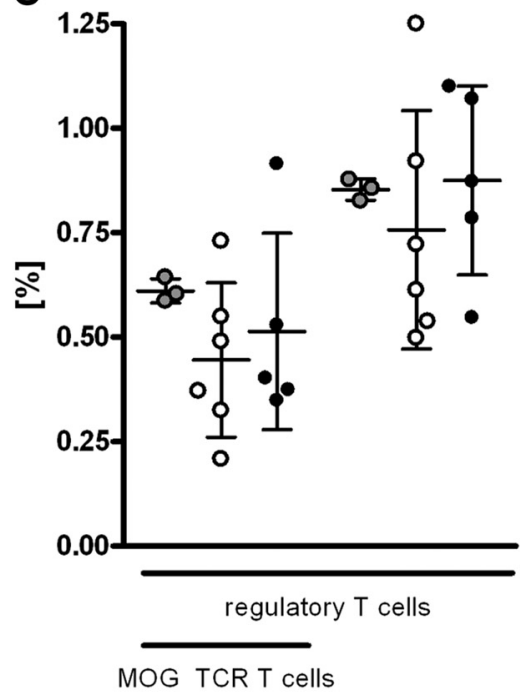

Figure 10. Immunological characterization of $\mathrm{CD}^{+}{ }^{+} \mathrm{T}$ cells obtained from cervical, mesenteric, inguinal, and lumbar lymph nodes and spleens of donor $2 D 2$ mice (naive, $N=3$, or vehicletreated, $N=6$; and mifepristone-/propranolol-treated mice, $N=5,7 \mathrm{~d}$ after MCAo for intravenous transfer into Rag- $1 K 0$ recipient mice. $A$, The number of MOG-specific CD4 ${ }^{+} T$ cells was similar in all three groups of donor mice. $\boldsymbol{B}$, Vehicle group of donor mice had less MOG-specific effector (Kruskal-Wallis with Mann-Whitney $U$ test, $U=1.000, p=0.048$ ) and central memory T cells (Kruskal-Wallis with Mann-Whitney $U$ test, $U=0.000, p=0.024$ ) compared with naive but not SNS/HPA block group of 2 2D2 donor mice. Cumulative number of effector memory $T$ cells was lower in vehicle compared with SNS/HPA block group of mice (Kruskal-Wallis with Mann-Whitney $U$ test, $U=3.000, p=0.030$ ). ${ }^{*} p<0.05$. C, The percentage of regulatory T cells among (MOG-specific) $\mathrm{CD} 4{ }^{+} \mathrm{T}$ cells was not affected by the group of donor $2 \mathrm{D} 2$ mice.
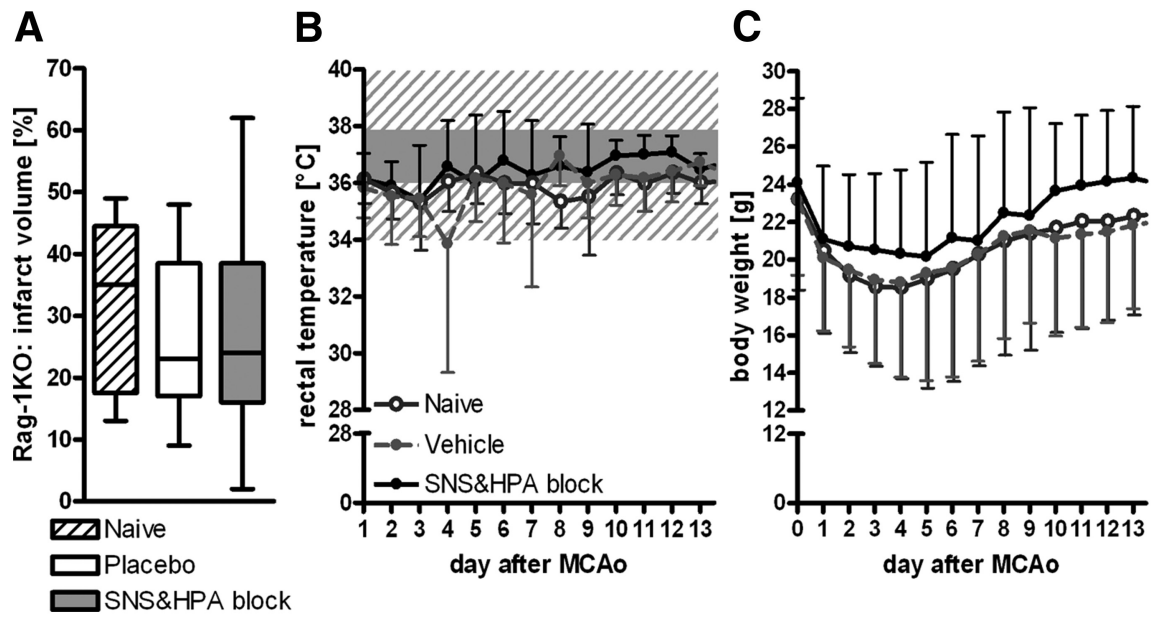

Figure 11. Infarct volumes, measured $24 \mathrm{~h}$ after MCAo $(\boldsymbol{A})$, body temperature $(\boldsymbol{B})$, and body weight $(\boldsymbol{C})$ of Rag-1KO mice, which were adoptively transferred $2 \times 10^{6} \mathrm{CD} 4^{+}$T cells from naive $(N=10)$, vehicle-treated $(N=13)$, or SNS/HPA-blocked $2 D 2$ donor mice $(N=13)$, did not differ significantly.

was increased in the SNS/HPA blockade compared with the vehicle group. However, TGF- $\beta 1$ is not only produced by regulatory $\mathrm{T}$ cells but predominantly by activated microglia/ macrophages (Doyle et al., 2010). Thus, SIDS might prevent potential harmful activation of $\mathrm{T}$ cells, including those reactive to CNS antigens, after brain injury.

Others have demonstrated that $\mathrm{T}$ cells specific to myelin antigens reduce secondary neurodegeneration and promote functional recovery after CNS injury (Moalem et al., 1999; Hauben et al., 2000; Lewitus et al., 2006), indicating that autoimmune responses may be protective under certain conditions. Interestingly, induction of oral tolerance to myelin basic protein (Becker et al., 1997) or MOG (Frenkel et al., 2003) via nasal administration was found to reduce infarct size and improve functional recovery. In contrast, sensitization with myelin antigens worsens the outcome in experimental models of cerebral ischemia (Becker et al., 1997). The mechanisms that govern protective versus nonprotective autoreactive T-cell responses after CNS injury are not understood but may depend on antigen specificity and phenotype of effector T cells, autoregulatory mechanisms including activation of regulatory T cells, genetic background, and on other factors that determine the strength and timing of autoreactive T-cell activation (Becker et al., 1997; Moalem et al., 1999; Jones et al., 2002, 2005; Frenkel et al., 2003; Lewitus et al., 2006).

Infections may stimulate antigenpresenting cells leading to the activation of autoreactive $T$ cells by otherwise innocuous antigens (Kissler et al., 2001; Hofstetter et al., 2003; Becker et al., 2011; Becker, 2012). In our experiments, we aimed to investigate direct effects of SIDS on CNS antigenspecific autoreactive immune responses. For the following reasons, we treated all mice independently of group assignment with the fluoroquinolone antibiotic enrofloxacin in an infectionpreventive manner. Spontaneous poststroke pneumonia is known to affect functional long-term outcome in experimental stroke (Hetze et al., 2013). In addition, the risk of poststroke infections increases with infarct size (Hug et al., 2009), and mice from the SNS/HPA blockade group had significantly smaller infarcts than mice from the vehicle group. Bacterial components, such as lipopolysaccharide, might boost CNS antigen-specific autoreactive immune responses in experimental as well as human stroke (Becker et al., 2005, 2011). Moreover, we have previously 
demonstrated that blocking SNS not only blocks stroke-induced immunodepression but also prevents poststroke infections (Prass et al., 2003, 2006). Finally, we have identified spontaneous poststroke infections as a contributing factor for CNS antigen-specific autoreactive immune responses in the mouse MCAo model (Klehmet et al., unpublished). Thus, poststroke infection is an interfering factor for investigations on CNS antigen-specific autoreactive immune responses in stroke. Therefore, we performed all experiments under preventive antibiotic treatment with enrofloxacin. We cannot exclude direct immunomodulatory effects by enrofloxacin. However, these effects would rather underestimate the observed CNS antigen-specific autoreactive immune responses because fluoroquinolones might exert anti-inflammatory effects (Dalhoff and Shalit, 2003), and our results suggest that coping with infections is more efficient when SIDS is blocked.

In line with previous studies on laboratory rodents (Vandeputte et al., 2010; Hetze et al., 2012; Li et al., 2013), mice displayed typical stroke-induced alterations in gait: asymmetry, increased stand duration and base of support, shorter stride lengths, reduced maximal contact area, and normalized swing speed. Additionally, with a median onset 9-14 d after stroke, 2D2 mice developed an EAE-like phenotype. MOG-specific T cells, in particular $\mathrm{CD} 4{ }^{+}$Th1 and Th17 cells, can mediate EAE (Linington et al., 1993; Genain et al., 1996; Stromnes et al., 2008; Bettini et al., 2009; Jäger et al., 2009). Neurological deficits caused directly by stroke typically subside within the first week after MCAo in mice. However, we observed thereafter that 2D2 mice developed a disease phenotype with symptoms reminiscent of EAE. Whereas stroke affects predominantly the performance of forepaw contralaterally to the ischemic lesion, EAE-like symptoms are characterized by progressive and ascending weakness/paralysis of the tail and limbs. The EAE-like phenotype occurred within 1 and 3 weeks after MCAo. Whereas this phenotype has been consistently observed in 2D2 mice, only a few wild-type mice develop mild EAE-like symptoms (data not shown).

The functional deficit in 2D2 mice manifesting clinically with flaccid rather than spastic paralysis was reminiscent of polyradiculitis, which was supported electrophysiologically with elongated F-wave latencies, suggesting demyelination, and histologically with infiltration of immune cells into the spinal nerve roots. This finding might be counterintuitive because most stroke patients suffer from a functional deficit, which is well explained by the corresponding contralateral ischemic brain lesion. However, it correlates with human studies demonstrating pathological ulnar F-wave variables of severely affected unconscious stroke patients (Chroni et al., 2006, 2007). In contrast to our primary hypothesis
B

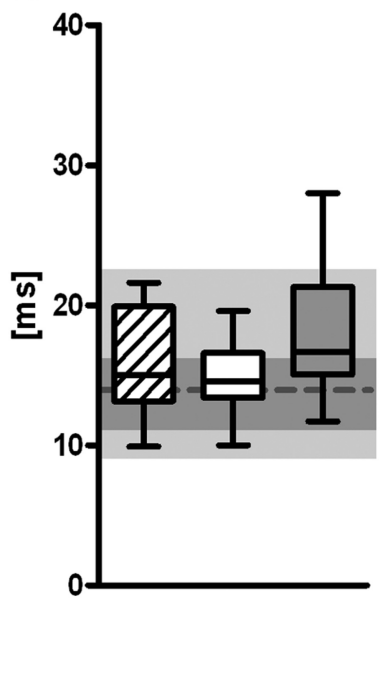

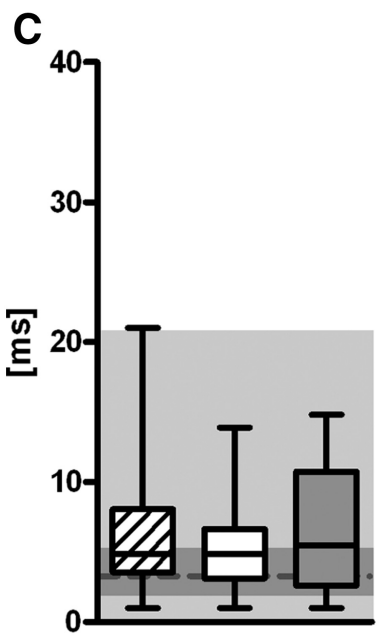

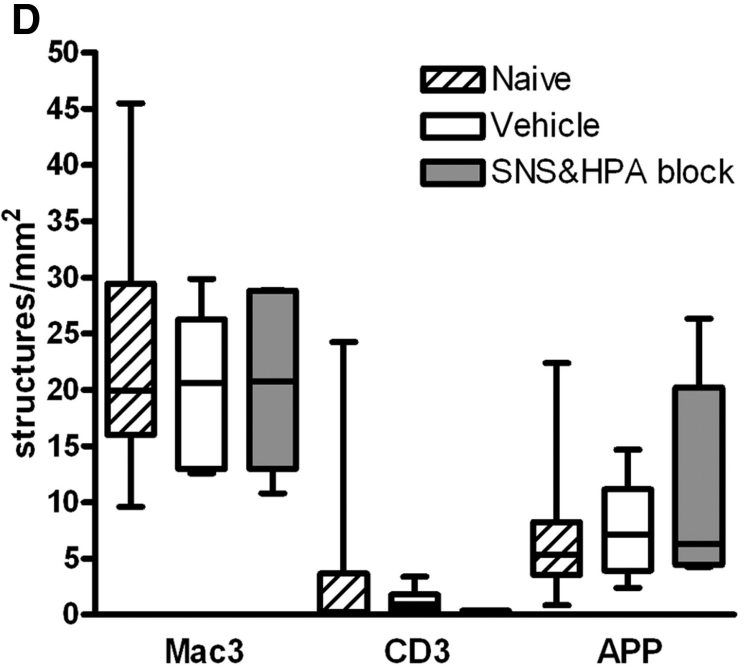

Figure 12. Following intravenous transfer of $2 \times 10^{6} \mathrm{CD}^{+} \mathrm{T}$ cells from naive $(N=10)$, vehicle-treated $(N=13)$, or SNS/HPA-blocked $2 D 2$ donor mice $(N=13)$, Rag-1KO mice developed milder EAE-like disease symptoms $(\boldsymbol{A} ;$; naive, $N=10$; vehicle, $N=9 ;$ SNS/HPA block, $N=9$; data are median \pm range) compared with 202 mice. F-wave latencies ( $\boldsymbol{B} ;$ naive, $N=20$; (16; SNS/HPA block, $N=14$ ) and F-wave chronodispersion upon sciatic nerve stimulation ( $($ ) remained at baselin $(N=19)$. Immunological infiltrates, composed of $\mathrm{MaC}^{+}$and $\mathrm{CD} 3^{+}$cells, APP ${ }^{+}$inflamed axons in the spinal nerve roots ( $\boldsymbol{D}$ naive, $N=9$; vehicle, $N=8 ; S N S / H P A$ block, $N=6$ ) were $\sim 4$ times less frequent than in 202 mice.

that SIDS prevents autoreactive immune responses, the polyradiculitis-like phenotype was rather diminished by blocking SIDS in 2D2 mice. These findings are difficult to interpret because SNS/HPA blockade also reduced infarct size and might reduce infection rate. However, our data suggest that neither lesion size nor poststroke infection accounts for the protective effect of SNS/HPA blockade against polyradiculitis. Moreover, adoptive transfer of $2 \mathrm{D} 2 \mathrm{CD} 4{ }^{+} \mathrm{T}$ cells to Rag-1KO mice suggests that blockade of SIDS does not further deteriorate functional outcome after experimental stroke, including the polyradiculitislike phenotype. This phenomenon needs to be addressed in further studies.

An unexpected finding of our study was the significantly infarct volume reducing effect of SNS/HPA blockade, which might be responsible for the better survival and temperature maintenance. Both stress systems typically potentiate each other in their effects (McEwen et al., 1987; Malbon and Hadcock, 1988; Mak et al., 1995). Because propranolol and mifepristone carry immuno- 
A

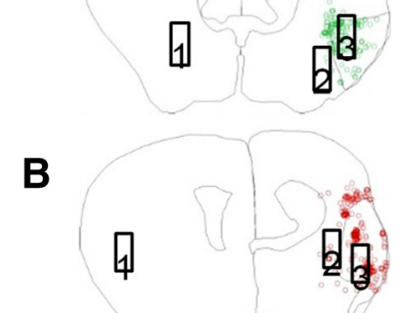

C

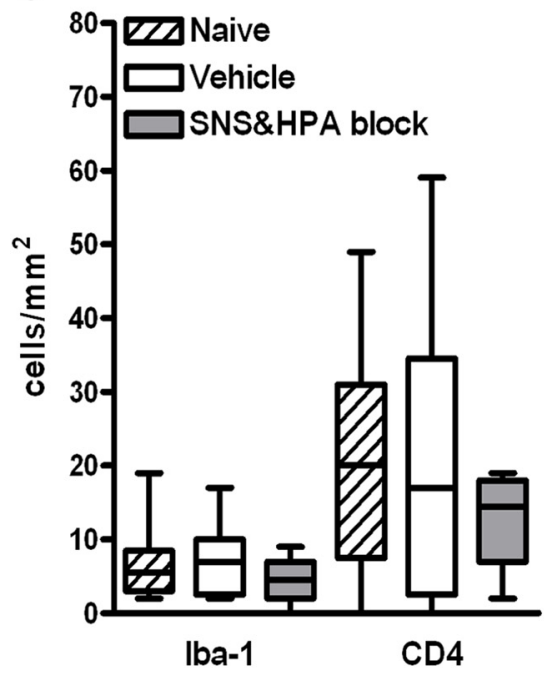

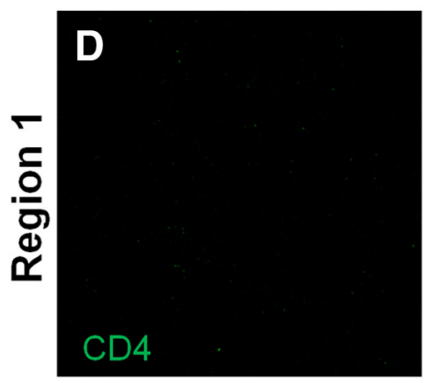
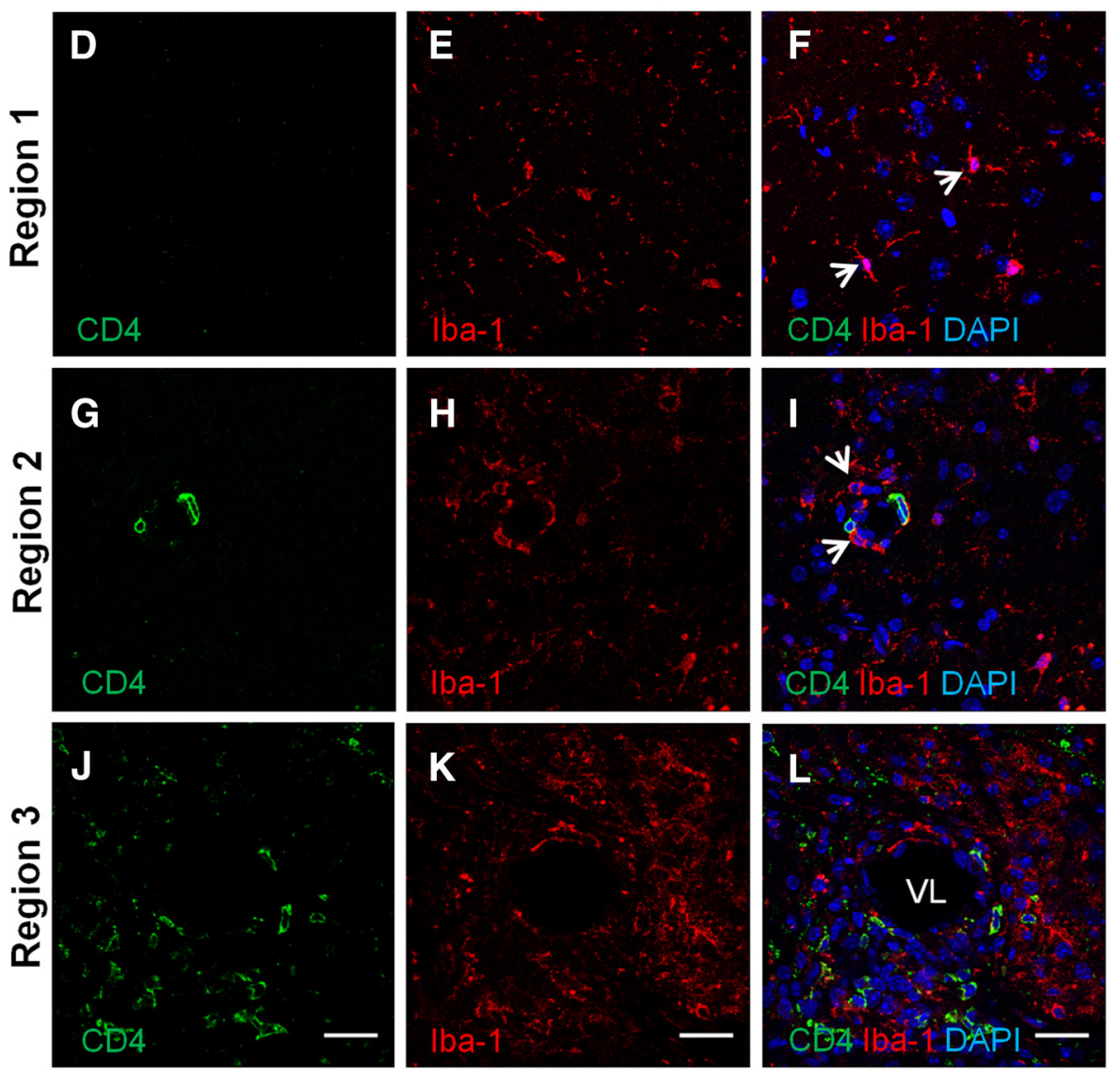

Figure 13. CD4 ${ }^{+} \mathrm{T}$ cells and Iba- $1^{+}$macrophages were found in Rag-1K0 mice brains $30 \mathrm{~d}$ after MCA0 and adoptive cell transfer from naive and treated $2 \mathrm{D} 2$ donors. The latter underwent MCA0. Images from CD4 (green) and Iba-1 (red) stained brain sections were taken from three regions indicated in $\boldsymbol{A}, \boldsymbol{B}$, with solid black line outlining ischemic core: Region 1, contralateral hemisphere; Region 2, nonischemic region adjacent to infarct in ipsilateral hemisphere; and Region 3, peri-infarct region in ipsilateral hemisphere. $\boldsymbol{D}-\boldsymbol{F}$, Thick arrow indicates the typical morphology of resting microglia with thin processes. $\mathbf{G}-\mathbf{I}$, Thick arrow indicates the morphology of activated microglia with an amoeboid-like shape, large cell body and thick processes. $J-L$, Immune cell infiltration was highest at and within ischemic core. C, Densities of $\mathrm{CD}^{+}{ }^{+}$and lba- ${ }^{+}$cells per $\mathrm{mm}^{2}$ Rag- $1 \mathrm{KO}$ mouse brain ipsilateral hemisphere in SNS/HPA block $(N=4)$, naive $(N=8)$, and vehicle group $(N=$ 8) $30 \mathrm{~d}$ after cell transfer and MCA0. VL, Vessel lumen. Scale bar, $20 \mu \mathrm{m}$.

modulatory properties, the smaller infarct volumes might be due to effects on early infiltrating immune cells and brain resident cells. Furthermore, different subsets of lymphocytes can exert detrimental as well as protective functions in cerebral ischemia (Yilmaz et al., 2006; Hurn et al., 2007; Liesz et al., 2009, 2011; Shichita et al., 2009; Kleinschnitz et al., 2010, 2013). However, because stress blockade prevented the development of large infarcts very early after stroke onset, immune-mediated mechanisms as primary sources for this are unlikely. Mechanistically, we excluded delayed infarct maturation, which has been observed in experimental stroke when studying mechanisms of inflammation and apoptosis (Du et al., 1996; Becker et al., 1997; Frenkel et al., 2003). CBF has been shown to inversely correlate with infarct volume (Dalkara et al., 1994). Propranolol might affect CBF (Edvinsson et al., 1979; Ley et al., 2009). CBF, measured by FAIR-MRI, was not altered by SNS/HPA blockade. However, we cannot exclude that mild but prolonged CBF elevations, which are below the detection threshold of FAIR-MRI (Leithner et al., 2008), contribute to the neuroprotective mechanism of SNS/HPA blockade. Further possibilities might include induction of Heat shock protein 72 by $\beta 2$-adrenoreceptor antagonist (Han et al., 2009) and antioxidant properties of mifepristone (Parthasarathy et al., 1994; Roberts et al., 1996; Behl et al., 1997; Antonawich et al., 1999; McCullers et al., 2002). Our data suggest that both mifepristone and propranolol are required to elicit neuroprotection in the SNS/HPA blockade group.
A limitation of our study is that we have measured CNS antigen-specific autoreactivity only at one time point after experimental stroke. Although the Elispot is considered a very sensitive method, this assay requires a high number of brain-infiltrating $\mathrm{T}$ cells to reliably measure CNS antigen-specific T-cell responses. Therefore, we performed Elispot experiments only at that time point where the number of brain-infiltrating $\mathrm{T}$ cells was sufficiently high to receive robust data. In the MCAo model, T-cell infiltration into the brain parenchyma is highest at day 14 and day 30 but relatively low at day 7 after stroke onset (Stubbe et al., 2013). Moreover, we considered this time window to be sufficient for MOG-specific CD4 ${ }^{+} \mathrm{T}$ cells to get primed (Janeway, 1989) and to differentiate into effector/memory $\mathrm{T}$ cells (Jäger et al., 2009). Another limitation of our study is that the main findings are based on investigations in $2 \mathrm{D} 2$ mice. Because the majority of their $\mathrm{CD} 4{ }^{+} \mathrm{T}$ cells carry a functional receptor for MOG, finding on CNS antigen-specific autoreactivity is most likely an overestimation of the situation in wild-type mice. We observed, even in wild-type C57BL/6J mice, Th1 responses against MOG in brain infiltrating lymphocytes $14 \mathrm{~d}$ after MCAo. However, the frequencies were much lower compared with $2 \mathrm{D} 2$ mice and only observed in animals with accompanying poststroke infections (Klehmet et al., unpublished).

The concept of SIDS has promoted the development of immunomodulatory treatment approaches for stroke (Shichita et al., 2009, 2012; Wong et al., 2011; Chamorro et al., 2012; Kamel 
and Iadecola, 2012). Modulating SIDS, however, might be a double-edged-sword approach reducing the risk for infection at cost of boosting detrimental autoimmune response against CNS antigens and worsening functional long-term outcome (Meisel and Meisel, 2011). Here we provide evidence that reversing SIDS by blocking body's stress axes increases autoreactive CNS antigen-specific immune responses in the brain but does not impair long-term functional outcome in our murine model of experimental stroke compared with vehicle treatment.

\section{References}

Adelmann M, Wood J, Benzel I, Fiori P, Lassmann H, Matthieu JM, Gardinier MV, Dornmair K, Linington C (1995) The N-terminal domain of the myelin oligodendrocyte glycoprotein (MOG) induces acute demyelinating experimental autoimmune encephalomyelitis in the Lewis rat. J Neuroimmunol 63:17-27. CrossRef Medline

Ando DG, Clayton J, Kono D, Urban JL, Sercarz EE (1989) Encephalitogenic T-cells in the B10.Pl model of experimental allergic encephalomyelitis (EAE) are of the Th-1 lymphokine subtype. Cell Immunol 124:132-143. CrossRef Medline

Antonawich FJ, Miller G, Rigsby DC, Davis JN (1999) Regulation of ischemic cell death by glucocorticoids and adrenocorticotropic hormone. Neuroscience 88:319-325. CrossRef Medline

Becker KJ (2012) Activation of immune responses to brain antigens after stroke. J Neurochem 123 [Suppl 2]:148-155.

Becker KJ, McCarron RM, Ruetzler C, Laban O, Sternberg E, Flanders KC, Hallenbeck JM (1997) Immunologic tolerance to myelin basic protein decreases stroke size after transient focal cerebral ischemia. Proc Natl Acad Sci U S A 94:10873-10878. CrossRef Medline

Becker KJ, Kindrick DL, Lester MP, Shea C, Ye ZC (2005) Sensitization to brain antigens after stroke is augmented by lipopolysaccharide. J Cereb Blood Flow Metab 25:1634-1644. CrossRef Medline

Becker KJ, Kalil AJ, Tanzi P, Zierath DK, Savos AV, Gee JM, Hadwin J, Carter KT, Shibata D, Cain KC (2011) Autoimmune responses to the brain after stroke are associated with worse outcome. Stroke 42:2763-2769. CrossRef Medline

Bederson JB, Pitts LH, Tsuji M, Nishimura MC, Davis RL, Bartkowski H (1986) Rat middle cerebral-artery occlusion: evaluation of the model and development of a neurologic examination. Stroke 17:472-476. CrossRef Medline

Behl C, Trapp T, Skutella T, Holsboer F (1997) Protection against oxidative stress-induced neuronal cell death: a novel role for RU486. Eur J Neurosci 9:912-920. CrossRef Medline

Bettelli E, Pagany M, Weiner HL, Linington C, Sobel RA, Kuchroo VK (2003) Myelin oligodendrocyte glycoprotein-specific T cell receptor transgenic mice develop spontaneous autoimmune optic neuritis. J Exp Med 197:1073-1081. CrossRef Medline

Bettini M, Rosenthal K, Evavold BD (2009) Pathogenic MOG-reactive $\mathrm{CD}^{+} \mathrm{T}$ cells require MOG-reactive $\mathrm{CD} 4^{+} \mathrm{T}$ cells for sustained CNS inflammation during chronic EAE. J Neuroimmunol 213:60-68. CrossRef Medline

Bornstein NM, Aronovich B, Korczyn AD, Shavit S, Michaelson DM, Chapman J (2001) Antibodies to brain antigens following stroke. Neurology 56:529-530. CrossRef Medline

Brunner C, Lassmann H, Waehneldt TV, Matthieu JM, Linington C (1989) Differential ultrastructural-localization of myelin basic-protein, myelin oligodendroglial glycoprotein, and 2',3'-cyclic nucleotide 3 '-phosphodiesterase in the CNS of adult-rats. J Neurochem 52:296-304. CrossRef Medline

Chamorro A, Urra X, Planas AM (2007) Infection after acute ischemic stroke: a manifestation of brain-induced immunodepression. Stroke 38: 1097-1103. CrossRef Medline

Chamorro Á, Meisel A, Planas AM, Urra X, van de Beek D, Veltkamp R (2012) The immunology of acute stroke. Nat Rev Neurol 8:401-410. CrossRef Medline

Chroni E, Katsoulas G, Argyriou AA, Sakellaropoulos GC, Polychronopoulos P, Nikiforidis G (2006) Level of consciousness as a conditioning factor of F wave generation in stroke patients. Clin Neurophysiol 117:315-319. CrossRef Medline

Chroni E, Argyriou AA, Katsoulas G, Polychronopoulos P (2007) Ulnar F wave generation assessed within 3 days after the onset of stroke in patients with relatively preserved level of consciousness. Clin Neurol Neurosurg 109:27-31. CrossRef Medline

Cua DJ, Sherlock J, Chen Y, Murphy CA, Joyce B, Seymour B, Lucian L, To W, Kwan S, Churakova T, Zurawski S, Wiekowski M, Lira SA, Gorman D, Kastelein RA, Sedgwick JD (2003) Interleukin-23 rather than interleukin-12 is the critical cytokine for autoimmune inflammation of the brain. Nature 421:744-748. CrossRef Medline

Dalhoff A, Shalit I (2003) Immunomodulatory effects of quinolones. Lancet Infect Dis 3:359-371. CrossRef Medline

Dalkara T, Morikawa E, Panahian N, Moskowitz MA (1994) Blood flowdependent functional recovery in a rat model of focal cerebral ischemia. Am J Physiol 267:H678-H683. Medline

Dambinova SA, Khounteev GA, Izykenova GA, Zavolokov IG, Ilyukhina AY, Skoromets AA (2003) Blood test detecting autoantibodies to N-methylD-aspartate neuroreceptors for evaluation of patients with transient ischemic attack and stroke. Clin Chem 49:1752-1762. CrossRef Medline

Dirnagl U, Members of the MCAO-SOP Group (2012) Standard operating procedures (SOP) in experimental stroke research: SOP for middle cerebral artery occlusion in the mouse. Nat Proc.

Dirnagl U, Klehmet J, Braun JS, Harms H, Meisel C, Ziemssen T, Prass K, Meisel A (2007) Stroke-induced immunodepression: experimental evidence and clinical relevance. Stroke 38:770-773. CrossRef Medline

Doyle KP, Cekanaviciute E, Mamer LE, Buckwalter MS (2010) TGFbeta signaling in the brain increases with aging and signals to astrocytes and innate immune cells in the weeks after stroke. J Neuroinflammation 7:62. CrossRef Medline

Du C, Hu R, Csernansky CA, Hsu CY, Choi DW (1996) Very delayed infarction after mild focal cerebral ischemia: a role for apoptosis? J Cereb Blood Flow Metab 16:195-201. CrossRef Medline

Edvinsson L, Lacombe P, Owman C, Reynier-Rebuffel AM, Seylaz J (1979) Quantitative changes in regional cerebral blood-flow of rats induced by alpha-adrenergic and beta-adrenergic stimulants. Acta Physiol Scand 107: 289-296. CrossRef Medline

Elenkov IJ, Wilder RL, Chrousos GP, Vizi ES (2000) The sympathetic nerve, an integrative interface between two supersystems: the brain and the immune system. Pharmacol Rev 52:595-638. Medline

Emsley HC, Hopkins SJ (2008) Acute ischaemic stroke and infection: recent and emerging concepts. Lancet Neurol 7:341-353. CrossRef Medline

Engel O, Meisel A (2010) Models of infection before and after stroke: investigating new targets. Infect Disord Drug Targets 10:98-104. CrossRef Medline

Finlayson O, Kapral M, Hall R, Asllani E, Selchen D, Saposnik G (2011) Risk factors, inpatient care, and outcomes of pneumonia after ischemic stroke. Neurology 77:1338-1345. CrossRef Medline

Fisher MA (2007) F-waves-physiology and clinical uses. Sci World J 7:144160. CrossRef Medline

Frenkel D, Huang Z, Maron R, Koldzic DN, Hancock WW, Moskowitz MA, Weiner HL (2003) Nasal vaccination with myelin oligodendrocyte glycoprotein reduces stroke size by inducing IL-10-producing CD4(+) T cells. J Immunol 171:6549-6555. CrossRef Medline

Global Burden of Disease Study (2012) Global Burden of Disease Study 2010. Lancet 380:2053-2260.

Gee JM, Kalil A, Thullbery M, Becker KJ (2008) Induction of immunologic tolerance to myelin basic protein prevents central nervous system autoimmunity and improves outcome after stroke. Stroke 39:1575-1582. CrossRef Medline

Gee JM, Zierath D, Hadwin J, Savos A, Kalil A, Thullbery M, Becker KJ (2009) Long term immunologic consequences of experimental stroke and mucosal tolerance. Exp Transl Stroke Med 1:3. CrossRef Medline

Genain CP, Abel K, Belmar N, Villinger F, Rosenberg DP, Linington C, Raine CS, Hauser SL (1996) Late complications of immune deviation therapy in a nonhuman primate. Science 274:2054-2057. CrossRef Medline

Han RQ, Ouyang YB, Xu L, Agrawal R, Patterson AJ, Giffard RG (2009) Postischemic brain injury is attenuated in mice lacking the beta2adrenergic receptor. Anesth Analg 108:280-287. CrossRef Medline

Hauben E, Nevo U, Yoles E, Moalem G, Agranov E, Mor F, Akselrod S, Neeman M, Cohen IR, Schwartz M (2000) Autoimmune T cells as potential neuroprotective therapy for spinal cord injury. Lancet 355:286287. CrossRef Medline

Hetze S, Römer C, Teufelhart C, Meisel A, Engel O (2012) Gait analysis as a method for assessing neurological outcome in a mouse model of stroke. J Neurosci Methods 206:7-14. CrossRef Medline 
Hetze S, Engel O, Römer C, Mueller S, Dirnagl U, Meisel C, Meisel A (2013) Superiority of preventive antibiotic treatment compared with standard treatment of poststroke pneumonia in experimental stroke: a bed to bench approach. J Cereb Blood Flow Metab 33:846-854. CrossRef Medline

Hofstetter HH, Sewell DL, Liu F, Sandor M, Forsthuber T, Lehmann PV, Fabry Z (2003) Autoreactive T cells promote post-traumatic healing in the central nervous system. J Neuroimmunol 134:25-34. CrossRef Medline

Hug A, Dalpke A, Wieczorek N, Giese T, Lorenz A, Auffarth G, Liesz A, Veltkamp R (2009) Infarct volume is a major determiner of post-stroke immune cell function and susceptibility to infection. Stroke 40:32263232. CrossRef Medline

Hurn PD, Subramanian S, Parker SM, Afentoulis ME, Kaler LJ, Vandenbark AA, Offner H (2007) T- and B-cell-deficient mice with experimental stroke have reduced lesion size and inflammation. J Cereb Blood Flow Metab 27:1798-1805. CrossRef Medline

Jäger A, Dardalhon V, Sobel RA, Bettelli E, Kuchroo VK (2009) Th1, Th17, and Th9 effector cells induce experimental autoimmune encephalomyelitis with different pathological phenotypes. J Immunol 183:7169-7177. CrossRef Medline

Janeway CA Jr (1989) The priming of helper T cells. Semin Immunol 1:13-20. Medline

Jones TB, Basso DM, Sodhi A, Pan JZ, Hart RP, MacCallum RC, Lee S, Whitacre CC, Popovich PG (2002) Pathological CNS autoimmune disease triggered by traumatic spinal cord injury: implications for autoimmune vaccine therapy. J Neurosci 22:2690-2700. Medline

Jones TB, Hart RP, Popovich PG (2005) Molecular control of physiological and pathological T-cell recruitment after mouse spinal cord injury. J Neurosci 25:6576-6583. CrossRef Medline

Kamel H, Iadecola C (2012) Brain-immune interactions and ischemic stroke: clinical implications. Arch Neurol 69:576-581. CrossRef Medline

Katzan IL, Cebul RD, Husak SH, Dawson NV, Baker DW (2003) The effect of pneumonia on mortality among patients hospitalized for acute stroke. Neurology 60:620-625. CrossRef Medline

Kissler S, Anderton SM, Wraith DC (2001) Antigen-presenting cell activation: a link between infection and autoimmunity? J Autoimmun 16:303308. CrossRef Medline

Kleinschnitz C, Kraft P, Dreykluft A, Hagedorn I, Göbel K, Schuhmann MK, Langhauser F, Helluy X, Schwarz T, Bittner S, Mayer CT, Brede M, Varallyay C, Pham M, Bendszus M, Jakob P, Magnus T, Meuth SG, Iwakura Y, Zernecke A, et al. (2013) Regulatory T cells are strong promoters of acute ischemic stroke in mice by inducing dysfunction of the cerebral microvasculature. Blood 121:679-691. CrossRef Medline

Kleinschnitz C, Schwab N, Kraft P, Hagedorn I, Dreykluft A, Schwarz T, Austinat M, Nieswandt B, Wiendl H, Stoll G (2010) Early detrimental T-cell effects in experimental cerebral ischemia are neither related to adaptive immunity nor thrombus formation. Blood 115:3835-3842. CrossRef Medline

Koennecke HC, Belz W, Berfelde D, Endres M, Fitzek S, Hamilton F, Kreitsch P, Mackert BM, Nabavi DG, Nolte CH, Pöhls W, Schmehl I, Schmitz B, von Brevern M, Walter G, Heuschmann PU, Berlin Stroke Register I (2011) Factors influencing in-hospital mortality and morbidity in patients treated on a stroke unit. Neurology 77:965-972. CrossRef Medline

Kuchroo VK, Anderson AC, Waldner H, Munder M, Bettelli E, Nicholson LB (2002) T-cell response in experimental autoimmune encephalomyelitis (EAE): role of self and cross-reactive antigens in shaping, tuning, and regulating the autopathogenic T cell repertoire. Annu Rev Immunol 20: 101-123. CrossRef Medline

Kumar S, Selim MH, Caplan LR (2010) Medical complications after stroke. Lancet Neurol 9:105-118. CrossRef Medline

Langrish CL, Chen Y, Blumenschein WM, Mattson J, Basham B, Sedgwick JD, McClanahan T, Kastelein RA, Cua DJ (2005) IL-23 drives a pathogenic $\mathrm{T}$ cell population that induces autoimmune inflammation. J Exp Med 201:233-240. CrossRef Medline

Leithner C, Gertz K, Schröck H, Priller J, Prass K, Steinbrink J, Villringer A, Endres M, Lindauer U, Dirnagl U, Royl G (2008) A flow sensitive alternating inversion recovery (FAIR)-MRI protocol to measure hemispheric cerebral blood flow in a mouse stroke model. Exp Neurol 210:118-127. CrossRef Medline

Leithner C, Müller S, Füchtemeier M, Lindauer U, Dirnagl U, Royl G (2010)
Determination of the brain-blood partition coefficient for water in mice using MRI. J Cereb Blood Flow Metab 30:1821-1824. CrossRef Medline

Lewitus GM, Kipnis J, Avidan H, Ben-Nun A, Schwartz M (2006) Neuroprotection induced by mucosal tolerance is epitope-dependent: conflicting effects in different strains. J Neuroimmunol 175:31-38. CrossRef Medline

Ley EJ, Scehnet J, Park R, Schroff S, Dagliyan G, Conti PS, Margulies DR, Salim A (2009) The in vivo effect of propranolol on cerebral perfusion and hypoxia after traumatic brain injury. J Trauma 66:154-159; discussion 159-161. CrossRef Medline

Li S, Shi Z, Zhang H, Liu X, Chen S, Jin J, Wang Y, Jia W, Li H (2013) Assessing gait impairment after permanent middle cerebral artery occlusion in rats using an automated computer-aided control system. Behav Brain Res 250C:174-191. CrossRef Medline

Liesz A, Suri-Payer E, Veltkamp C, Doerr H, Sommer C, Rivest S, Giese T, Veltkamp R (2009) Regulatory T cells are key cerebroprotective immunomodulators in acute experimental stroke. Nat Med 15:192-199. CrossRef Medline

Liesz A, Zhou W, Mracskó É, Karcher S, Bauer H, Schwarting S, Sun L, Bruder D, Stegemann S, Cerwenka A, Sommer C, Dalpke AH, Veltkamp R (2011) Inhibition of lymphocyte trafficking shields the brain against deleterious neuroinflammation after stroke. Brain 134:704-720. CrossRef Medline

Linington C, Berger T, Perry L, Weerth S, Hinze-Selch D, Zhang Y, Lu HC, Lassmann H, Wekerle H (1993) T cells specific for the myelin oligodendrocyte glycoprotein mediate an unusual autoimmune inflammatory response in the central nervous system. Eur J Immunol 23:1364-1372. CrossRef Medline

Livnat S, Felten SY, Carlson SL, Bellinger DL, Felten DL (1985) Involvement of peripheral and central catecholamine systems in neural-immune interactions. J Neuroimmunol 10:5-30. CrossRef Medline

MacDonald KD, Chang HY, Mitzner W (2009) An improved simple method of mouse lung intubation. J Appl Physiol 106:984-987. CrossRef Medline

Mak JC, Nishikawa M, Shirasaki H, Miyayasu K, Barnes PJ (1995) Protective effects of a glucocorticoid on downregulation of pulmonary beta 2-adrenergic receptors in vivo. J Clin Invest 96:99-106. CrossRef Medline

Malbon CC, Hadcock JR (1988) Evidence that glucocorticoid response elements in the $5^{\prime}$-noncoding region of the hamster beta 2 -adrenergic receptor gene are obligate for glucocorticoid regulation of receptor mRNA levels. Biochem Biophys Res Commun 154:676-681. CrossRef Medline

McCullers DL, Sullivan PG, Scheff SW, Herman JP (2002) Mifepristone protects CA1 hippocampal neurons following traumatic brain injury in rat. Neuroscience 109:219-230. CrossRef Medline

McEwen B, Brinton R, Harrelson A, Rostene W (1987) Modulatory interactions between steroid hormones, neurotransmitters and neuropeptides in hippocampus. Adv Biochem Psychopharmacol 43:87-102. Medline

Meisel A, Meisel C (2008) Stroke-induced immunodepression: consequences, mechanisms and therapeutic implications. Future Neurol 3:551-563. CrossRef

Meisel C, Meisel A (2011) Suppressing immunosuppression after stroke. N Engl J Med 365:2134-2136. CrossRef Medline

Meisel C, Prass K, Braun J, Victorov I, Wolf T, Megow D, Halle E, Volk HD, Dirnagl U, Meisel A (2004) Preventive antibacterial treatment improves the general medical and neurological outcome in a mouse model of stroke. Stroke 35:2-6. CrossRef Medline

Meisel C, Schwab JM, Prass K, Meisel A, Dirnagl U (2005) Central nervous system injury-induced immune deficiency syndrome. Nat Rev Neurosci 6:775-786. CrossRef Medline

Millan M, Davalos A (2006) The need for new therapies for acute ischaemic stroke. Cerebrovasc Dis 22:3-9. CrossRef

Moalem G, Leibowitz-Amit R, Yoles E, Mor F, Cohen IR, Schwartz M (1999) Autoimmune $\mathrm{T}$ cells protect neurons from secondary degeneration after central nervous system axotomy. Nat Med 5:49-55. CrossRef Medline

Parthasarathy S, Morales AJ, Murphy AA (1994) Antioxidant: a new role for RU-486 and related compounds. J Clin Invest 94:1990-1995. CrossRef Medline

Prass K, Meisel C, Höflich C, Braun J, Halle E, Wolf T, Ruscher K, Victorov IV, Priller J, Dirnagl U, Volk HD, Meisel A (2003) Stroke-induced immunodeficiency promotes spontaneous bacterial infections and is mediated by sympathetic activation reversal by poststroke $\mathrm{T}$ helper cell type 1-like immunostimulation. J Exp Med 198:725-736. CrossRef Medline 
Prass K, Braun JS, Dirnagl U, Meisel C, Meisel A (2006) Stroke propagates bacterial aspiration to pneumonia in a model of cerebral ischemia. Stroke 37:2607-2612. CrossRef Medline

Rivers TM, Sprunt DH, Berry GP (1933) Observations on attempts to produce acute disseminated encephalomyelitis in monkeys. J Exp Med 58: 39-53. CrossRef Medline

Roberts CP, Murphy AA, Santanam N, Parthasarathy S (1996) The effect of RU 486 and related compounds on cultured macrophage differentiation and function. Am J Obstet Gynecol 175:248-257; discussion 257-259. CrossRef Medline

Rocco A, Fam G, Sykora M, Diedler J, Nagel S, Ringleb P (2013) Poststroke infections are an independent risk factor for poor functional outcome after three-months in thrombolysed stroke patients. Int J Stroke 8:639644. CrossRef Medline

Royl G, Balkaya M, Lehmann S, Lehnardt S, Stohlmann K, Lindauer U, Endres M, Dirnagl U, Meisel A (2009) Effects of the PDE5-inhibitor vardenafil in a mouse stroke model. Brain Res 1265:148-157. CrossRef Medline

Sanders VM, Baker RA, Ramer-Quinn DS, Kasprowicz DJ, Fuchs BA, Street NE (1997) Differential expression of the beta2-adrenergic receptor by Th1 and Th2 clones: implications for cytokine production and B cell help. J Immunol 158:4200-4210. Medline

Shichita T, Sugiyama Y, Ooboshi H, Sugimori H, Nakagawa R, Takada I, Iwaki T, Okada Y, Iida M, Cua DJ, Iwakura Y, Yoshimura A (2009) Pivotal role of cerebral interleukin-17-producing gammasT cells in the delayed phase of ischemic brain injury. Nat Med 15:946-950. CrossRef Medline

Shichita T, Ago T, Kamouchi M, Kitazono T, Yoshimura A, Ooboshi H (2012) Novel therapeutic strategies targeting innate immune responses and early inflammation after stroke. J Neurochem 123 [Suppl 2]:29-38.

Stromnes IM, Cerretti LM, Liggitt D, Harris RA, Goverman JM (2008) Differential regulation of central nervous system autoimmunity by $\mathrm{T}(\mathrm{H}) 1$ and $\mathrm{T}(\mathrm{H}) 17$ cells. Nat Med 14:337-342. CrossRef Medline

Stubbe T, Ebner F, Richter D, Engel O, Randolf Engel O, Klehmet J, Royl G, Meisel A, Nitsch R, Meisel C, Brandt C (2013) Regulatory T cells accumulate and proliferate in the ischemic hemisphere for up to 30 days after MCAO. J Cereb Blood Flow Metab 33:37-47. CrossRef Medline
Tischner D, Reichardt HM (2007) Glucocorticoids in the control of neuroinflammation. Mol Cell Endocrinol 275:62-70. CrossRef Medline

Tracey KJ (2002) The inflammatory reflex. Nature 420:853-859. CrossRef Medline

Tuosto L, Cundari E, Gilardini Montani MS, Piccolella E (1994) Analysis of susceptibility of mature human $\mathrm{T}$ lymphocytes to dexamethasoneinduced apoptosis. Eur J Immunol 24:1061-1065. CrossRef Medline

Vandeputte C, Taymans JM, Casteels C, Coun F, Ni Y, Van Laere K, Baekelandt V (2010) Automated quantitative gait analysis in animal models of movement disorders. BMC Neurosci 11:92. CrossRef Medline

Vega JL, Ganea D, Jonakait GM (2003) Acute down-regulation of antibody production following spinal cord injury: role of systemic catecholamines. J Neuropathol Exp Neurol 62:848-854. Medline

Vogelgesang A, Becker KJ, Dressel A (2014) Immunological consequences of ischemic stroke. Acta Neurol Scand 129:1-12. CrossRef Medline

Wang FI, Hinton DR, Gilmore W, Trousdale MD, Fleming JO (1992) Sequential infection of glial cells by the murine hepatitis virus JHM strain (MHV-4) leads to a characteristic distribution of demyelination. Lab Invest 66:744-754. Medline

Westendorp WF, Nederkoorn PJ, Vermeij JD, Dijkgraaf MG, van de Beek D (2011) Post-stroke infection: a systematic review and meta-analysis. BMC Neurol 11:110. CrossRef Medline

Whalen MM, Bankhurst AD (1990) Effects of beta-adrenergic receptor activation, cholera toxin and forskolin on human natural killer cell function. Biochem J 272:327-331. Medline

Woiciechowsky C, Schoning B, Lanksch WR, Volk HD, Docke WD (1999) Mechanisms of brain-mediated systemic anti-inflammatory syndrome causing immunodepression. J Mol Med (Berl) 77:769-780. CrossRef Medline

Wong CH, Jenne CN, Lee WY, Léger C, Kubes P (2011) Functional innervation of hepatic iNKT cells is immunosuppressive following stroke. Science 334:101-105. CrossRef Medline

Yilmaz G, Arumugam TV, Stokes KY, Granger DN (2006) Role of T lymphocytes and interferon-gamma in ischemic stroke. Circulation 113: 2105-2112. CrossRef Medline 